\title{
The effect of improving cow productivity, fertility, and longevity on the global warming potential of dairy systems
}

\author{
M. J. Bell, ${ }^{\star 1}$ E. Wall, ${ }^{*}$ G. Russell, $†$ G. Simm, ${ }^{*}$ and A. W. Stott ${ }^{\star}$ \\ *Scottish Agricultural College (SAC), West Mains Road, Edinburgh, EH9 3JG, United Kingdom \\ †School of GeoSciences, University of Edinburgh, West Mains Road, Edinburgh, EH9 3JN, United Kingdom
}

\begin{abstract}
This study compared the environmental impact of a range of dairy production systems in terms of their global warming potential (GWP, expressed as carbon dioxide equivalents, $\mathrm{CO}_{2}$-eq.) and associated land use, and explored the efficacy of reducing said impact. Models were developed using the unique data generated from a long-term genetic line $\times$ feeding system experiment. Holstein-Friesian cows were selected to represent the UK average for milk fat plus protein production (control line) or were selected for increased milk fat plus protein production (select line). In addition, cows received a low forage diet ( $50 \%$ forage) with no grazing or were on a high forage ( $75 \%$ forage) diet with summer grazing. A Markov chain approach was used to describe the herd structure and help estimate the GWP per year and land required per cow for the 4 alternative systems and the herd average using a partial life cycle assessment. The $\mathrm{CO}_{2}$-eq. emissions were expressed per kilogram of energy-corrected milk (ECM) and per hectare of land use, as well as land required per kilogram of ECM. The effects of a phenotypic and genetic standard deviation unit improvement on herd feed utilization efficiency, ECM yield, calving interval length, and incidence of involuntary culling were assessed. The low forage (nongrazing) feeding system with select cows produced the lowest $\mathrm{CO}_{2}$-eq. emissions of $1.1 \mathrm{~kg} / \mathrm{kg}$ of ECM and land use of $0.65 \mathrm{~m}^{2} / \mathrm{kg}$ of ECM but the highest $\mathrm{CO}_{2}$-eq. emissions of $16.1 \mathrm{t} / \mathrm{ha}$ of the production systems studied. Within the herd, an improvement of 1 standard deviation in feed utilization efficiency was the only trait of those studied that would significantly reduce the reliance of the farming system on bought-in synthetic fertilizer and concentrate feed, as well as reduce the average $\mathrm{CO}_{2}$-eq. emissions and land use of the herd (both by about $6.5 \%$, of which about $4 \%$ would be achievable through selective breed-
\end{abstract}

Received November 19, 2010.

Accepted February 10, 2011.

${ }^{1}$ Corresponding author: Matt.Bell@unimelb.edu.au ing). Within production systems, reductions in $\mathrm{CO}_{2}$-eq. emissions per kilogram of ECM and $\mathrm{CO}_{2}$-eq. emissions per hectare were also achievable by an improvement in feed utilization. This study allowed development of models that harness the biological trait variation in the animal to improve the environmental impact of the farming system. Genetic selection for efficient feed use for milk production according to feeding system can bring about reductions in system nutrient requirements, $\mathrm{CO}_{2}$-eq. emissions, and land use per unit product.

Key words: dairy cow, production system, global warming potential, land use

\section{INTRODUCTION}

Capper et al. (2009) highlighted the need to adopt management practices and technologies that improve productive efficiency to meet increasing product demand (FAO, 2010) while minimizing the environmental impact of dairy production. The environmental impact of a system can be evaluated by assessing the global warming potential (GWP) in carbon dioxide equivalent $\left(\mathbf{C O}_{2}\right.$-eq. $)$ emissions and resource use (in the context of this paper, land use) associated with production (Guinée et al., 2002). The land use associated with a dairy system reflects the cow's requirement for food. The life cycle assessment (LCA) of a product has become an internationally accepted method for assessing its potential environmental impact (Guinée et al., 2002). Several studies (Cederberg and Mattsson, 2000; Casey and Holden, 2005; Thomassen et al., 2008; Basset-Mens et al., 2009; FAO, 2010) have assessed the $\mathrm{CO}_{2}$-eq. emissions of producing $1 \mathrm{~kg}$ of ECM leaving the farm-gate (the functional unit as defined by Guinée et al., 2002) for a range of dairy production systems using national data. The use of ECM was first proposed by Sjaunja et al. (1990) to adjust milk yield for its fat and protein contents, which significantly affects the energy required to produce milk.

Globally, the dairy sector contributes about $4 \%$ of $\mathrm{CO}_{2}$-eq. greenhouse gas (GHG) emissions (FAO, 2010). Carbon dioxide $\left(\mathrm{CO}_{2}\right)$, methane $\left(\mathrm{CH}_{4}\right)$, and nitrous oxide $\left(\mathrm{N}_{2} \mathrm{O}\right)$, as well as indirect sources of nitrogen from 
nitrogen oxides $\left(\mathrm{NO}_{\mathrm{x}}\right)$ and ammonia $\left(\mathrm{NH}_{3}\right)$, contribute to the $\mathrm{CO}_{2}$-eq. emissions of a production system. In developed countries, $52 \%$ of dairy sector $\mathrm{CO}_{2}$-eq. emissions are estimated to be in the form of $\mathrm{CH}_{4}, 27 \%$ as $\mathrm{N}_{2} \mathrm{O}$, and $21 \%$ as $\mathrm{CO}_{2}$ (FAO, 2010). It is well recognized that the most important GHG from ruminant production systems is $\mathrm{CH}_{4}$ from enteric fermentation, representing a significant loss of between 2 and $12 \%$ of gross energy intake (Martin et al., 2010). Nutritional manipulation of the diet is a mitigation option that can be applied immediately through adjustments to management (Martin et al., 2010), whereas selective breeding on a production trait such as feed utilization efficiency would take several years before any genetic improvement is seen (Hegarty, 2005).

Garnsworthy (2004) found that a high-milk-producing system with high health and fertility status offers scope for minimizing $\mathrm{CH}_{4}$ emissions per kilogram of milk by reducing the number of milking herd replacements retained and the calving interval length and increasing the average daily milk yield of the herd. However, because of breeding largely for increased milk production in Holstein-Friesian dairy cows over the last $25 \mathrm{yr}$, genetic merit for fitness traits such as health and fertility has declined (Pryce et al., 1999). Garnsworthy (2004) modeled fertility parameters and found that the emissions of $\mathrm{CH}_{4}$ have risen by $11 \%$ per herd compared with 1995 fertility levels in the UK. In a previous study on the "Langhill" cows, which are also the subject of this study (Bell et al., 2010a), poor fertility (longer days from calving to conception and conception failure) and poor health (calving assistance, abortion and mastitis) were risk factors to survival.

Wall et al. (2010) highlighted the need to assess the role that genetic improvement can have in a wholesystem approach to GHG emissions, including its interaction with feeding and management systems. The production systems in that study were designed to represent average and high genetic lines for production on low (nongrazed) or high forage (with grazing) feeding systems (Pollott and Coffey, 2008) but, in contrast to other studies, were within the same farming unit, thus minimizing the effect of extraneous factors. Dairy systems can range considerably in their level of production and efficiency with regard to feed intake, milk yield, fertility, and health, all of which can influence survival, $\mathrm{CO}_{2}$-eq. emissions, and the requirement for land. To model dairy systems within the same herd and farming unit on a comparative period, while incorporating the cyclical nature of individual systems and the implications of changes to these systems, a Markov chain (Agrawal and Heady, 1972) can be used. A Markov chain approach has been used to model the effects of production factors such as disease (Allore and Erb,
1999) and fertility (Stott et al., 1999; Garnsworthy, 2004) on a herd. Stott et al. (1999) used a Markov chain to establish the economic optimum total cost of fertility in a dairy herd. Santarossa et al. (2004) incorporated this approach in an assessment of the sustainability of dairying.

The objectives of the present study were (1) to model the $\mathrm{CO}_{2}$-eq. emissions and land use of the Langhill experimental herd in Scotland using a Markov chain and LCA approach; (2) to assess, for each production system within the herd, the effect of a phenotypic and genetic standard deviation improvement in herd feed utilization efficiency, ECM yield, calving interval length, and involuntary culling on the $\mathrm{CO}_{2}$-eq. emissions and land use of the herd; (3) to assess the effect of the same improvements on $\mathrm{CO}_{2}$-eq. emissions and land use per kilogram of ECM and $\mathrm{CO}_{2}$-eq. emissions per hectare; and (4) to suggest feasible mitigation options.

\section{MATERIALS AND METHODS}

\section{Production Systems}

The detailed and extensive data used in this study were obtained from the Langhill herd of HolsteinFriesian cows over a 7 -yr period. The cows were on a long-term genetic line $\times$ feeding systems experiment at the Scottish Agricultural College (SAC) Dairy Research Centre in Scotland (Pollott and Coffey, 2008), one of the longest running selection experiments in dairy cattle in the world. The production systems within the herd were designed to represent a range of Holstein-Friesian dairy systems. The Langhill herd comprises genetic lines selected for kilograms of milk fat plus protein (select line) or selected to remain close to the average genetic merit for milk fat plus protein production for all animals evaluated in the UK (control line). Chagunda et al. (2009) reported the PTA for kilograms of milk fat plus protein production for bulls used on select and control genetic line cows to be $937 \pm 231$ and $263 \pm 185$ $\mathrm{kg}$ milk yield, $34 \pm 5$ and $3 \pm 7 \mathrm{~kg}$ of milk fat, and 31 \pm 4 and $5 \pm 5 \mathrm{~kg}$ of milk protein, respectively (mean $\pm \mathrm{SD})$.

The herd was managed with one group kept indoors on a low forage diet (low forage feeding system) and the other group on a high forage diet with summer grazing (high forage feeding system). The low forage diet consisted of, on average, $50 \%$ home-grown forage (grass silage, maize silage, and ammonia-treated wheat silage) and the high forage diet was, on average, $75 \%$ home-grown forage in the DM, with high forage cows having access to pasture for $55 \%$ of the days in a year on average (typically indoors from November to April). The remaining proportion of the diet was bought-in 
concentrate feed in the form of wheat grain, sugar beet pulp, soybean meal, rapeseed meal, wheat and barley distillers dark grains, and vitamin and mineral supplement. Similar numbers within each select and control genetic line were offered each diet as a TMR or in the parlor. Cows were fed ad libitum and feed intakes were recorded using $\mathrm{HOKO}$ automatic feed measurement gates (Insentec BV, Marknesse, the Netherlands) for 3 out of $6 \mathrm{~d}$ when cows were lactating. When cows were at pasture, herbage intake was estimated using the National Research Council (2001) DM intake prediction model that, in Bell et al. (2010b), was shown to be an appropriate method for this study. The chemical composition of the pasture was based on the average chemical composition of 17 weekly samples of herbage for analysis, which were taken only during the summer grazing period of 2006 . The average chemical composition of the pasture was $195 \pm 38,627 \pm 18,225 \pm$ 31 , and $43 \pm 17 \mathrm{~g} / \mathrm{kg}$ for $\mathrm{DM}, \mathrm{NDF}, \mathrm{CP}$, and sugar, and $10.5 \pm 0.2 \mathrm{MJ} / \mathrm{kg}$ for $\mathrm{ME}$, respectively. The ME content of the diets was calculated using the prediction equation developed by Thomas et al. (1988). The gross energy (GE) of pasture and feed consumed by replacement animals was assumed to be $18.45 \mathrm{MJ} / \mathrm{kg}$ of DM for nitrogen excretion calculations (UKGGI, 2010). Food analysis was carried out at the SAC Analytical Laboratory (Edinburgh, UK). The average percentage of dietary components in the DM of feed consumed during the study period for low and high forage milking herd diets, respectively, were grass silage 31.2 and $24.0 \%$, maize silage 9.4 and $8.2 \%$, ammonia-treated wheat silage 9.4 and $8.6 \%$, bought-in concentrate feed 50.0 and $23.8 \%$, pasture 0 and $35.4 \%$, and negligible mineral supplement. While the cows were indoors, low and high forage diets were formulated to achieve target ME contents of 12.3 and $11.5 \mathrm{MJ} / \mathrm{kg}$ of $\mathrm{DM}$, with $\mathrm{CP}$ contents of 185 and $180 \mathrm{~g} / \mathrm{kg}$ of DM, respectively. Production systems were defined as low forage control (LFC), low forage select (LFS), high forage control (HFC), and high forage select (HFS).

Cows were milked 3 times a day and milk fat and protein contents were recorded weekly. Following Sjaunja et al. (1990), the daily milk yield was converted to ECM yield using milk fat and protein yields based on the weekly fat and protein content of milk:

$$
\begin{gathered}
\mathrm{ECM}(\mathrm{kg} / \mathrm{d})=0.25 \times \mathrm{kg} \text { of milk yield }+12.2 \\
\times \mathrm{kg} \text { of fat yield }+7.7 \times \mathrm{kg} \text { of protein yield }
\end{gathered}
$$

Cow BW was measured 3 times each day. Culling time was defined as the date on which a cow's productive life ceased. The reasons for culling cows before their fourth lactation were normally poor fertility, abortion, or mastitis (Bell et al., 2010a).

\section{Markov Chain}

A Markov chain can be used to represent a herd as a vector of states (s) that cows occupy at a given point in time (Stott et al., 1999). These states may represent lactation number, stage of lactation, disease status, or pregnancy status, depending upon the objectives of the study. The vector of states at time $t$ is multiplied by a matrix of transition probabilities $(\mathrm{s} \times \mathrm{s})$ to give the vector of states at time $t+1$. If the transition matrix is constant for all stages; that is, the model is stationary, then repeated matrix multiplication will produce a fixed long-run vector (steady state), which is independent of the initial state vector. This long-run steady-state vector provides a useful basis for comparative assessment of the alternative dairy systems. Modeling the herd structure using a Markov chain also allows changes in dairy system parameters to be systematically assessed at the herd level. Previous studies on the Langhill herd have typically modeled the production systems (genetic line $\times$ feeding system) within the herd using daily average values (Chagunda et al., 2009).

To model the herd structure over time with a Markov chain, a stage interval of $60 \mathrm{~d}$ was used. A maximum calving interval of $600 \mathrm{~d}$ covering all cows was assumed for lactations $1,2,3$, and $3+$, so the state vector consisted of 10 within-calving interval periods of $60 \mathrm{~d}$ for each of 4 lactations (40 states in total). The proportion of the milking herd falling within each state depended on when cows calved or whether they were culled from the herd. Once cows calved, they would move on to the next lactation unless culled from the herd. The percentage of cows calved and culled during each state for each lactation and production system is shown in Table 1. These data were used to construct a transition matrix for a Markov chain for each production system. The percentages calved and culled were converted into a transition probability from lactation $n$ to $n+1$ and from lactation 1 to $n$, respectively. Cows culled were therefore assumed to be replaced within 1 stage interval, reflecting experimental practice whereby treatment group sizes are maintained within the herd. The data in Table 1 were accumulated over $7 \mathrm{yr}$ and thus give the best available estimate of the calving and culling performance of each system under the conditions operating on the Langhill herd at that time (Pollott and Coffey, 2008). The protocol requires cows to be kept in the herd for at least 3 lactations unless cow welfare dictates that culling is necessary or a suitable heifer of the same genetic line becomes available so that a cow of greater 
Table 1. Percentage of cows across states, lactations, and production systems ${ }^{1}$ studied that calved or were culled (from farm data) and the long-run steady-state vector obtained from the Markov chain

\begin{tabular}{|c|c|c|c|c|c|c|c|c|c|c|c|c|c|}
\hline \multirow[b]{2}{*}{ Lactation } & \multirow[b]{2}{*}{ State $^{2}$} & \multicolumn{4}{|c|}{ Calved (\%) } & \multicolumn{4}{|c|}{ Culled (\%) } & \multicolumn{4}{|c|}{ Steady state (\%) } \\
\hline & & LFC & LFS & HFC & HFS & LFC & LFS & HFC & HFS & LFC & LFS & $\mathrm{HFC}$ & HFS \\
\hline & 3 & 0.0 & 0.0 & 0.0 & 0.0 & 4.7 & 6.2 & 4.0 & 0.0 & 4.8 & 4.6 & 4.7 & 4.1 \\
\hline & 4 & 0.0 & 0.0 & 0.0 & 0.0 & 2.3 & 3.1 & 4.0 & 0.0 & 4.6 & 4.3 & 4.5 & 4.1 \\
\hline & 5 & 2.2 & 1.3 & 1.3 & 1.4 & 2.3 & 6.2 & 4.0 & 4.9 & 4.5 & 4.2 & 4.4 & 4.1 \\
\hline & 8 & 12.9 & 22.5 & 19.2 & 19.4 & 0.0 & 3.1 & 0.0 & 2.4 & 1.4 & 1.7 & 1.5 & 1.7 \\
\hline & 9 & 5.4 & 8.8 & 5.1 & 5.6 & 2.3 & 0.0 & 8.0 & 0.0 & 1.2 & 1.3 & 1.2 & 1.3 \\
\hline & 10 & 3.2 & 5.0 & 2.6 & 12.5 & 0.0 & 4.6 & 0.0 & 0.0 & 1.2 & 1.2 & 1.0 & 1.2 \\
\hline \multirow[t]{5}{*}{2} & 1 & 0.0 & 0.0 & 0.0 & 0.0 & 7.0 & 0.0 & 4.0 & 2.4 & 4.1 & 3.7 & 3.8 & 3.6 \\
\hline & 2 & 0.0 & 0.0 & 0.0 & 0.0 & 2.3 & 1.5 & 0.0 & 2.4 & 3.8 & 3.7 & 3.6 & 3.5 \\
\hline & 3 & 0.0 & 0.0 & 0.0 & 0.0 & 0.0 & 4.6 & 8.0 & 0.0 & 3.7 & 3.6 & 3.6 & 3.5 \\
\hline & 4 & 0.0 & 0.0 & 1.5 & 2.1 & 4.7 & 4.6 & 0.0 & 4.9 & 3.7 & 3.4 & 3.3 & 3.5 \\
\hline & 10 & 3.6 & 3.9 & 1.5 & 2.1 & 0.0 & 1.5 & 4.0 & 2.4 & 0.9 & 0.9 & 0.8 & 1.0 \\
\hline \multirow[t]{10}{*}{3} & 1 & 0.0 & 0.0 & 0.0 & 0.0 & 0.0 & 0.0 & 8.0 & 0.0 & 3.2 & 3.0 & 2.9 & 3.2 \\
\hline & 2 & 0.0 & 0.0 & 0.0 & 0.0 & 0.0 & 1.5 & 0.0 & 0.0 & 3.2 & 3.0 & 2.7 & 3.2 \\
\hline & 3 & 0.0 & 0.0 & 0.0 & 0.0 & 2.3 & 4.6 & 0.0 & 2.4 & 3.2 & 2.9 & 2.7 & 3.2 \\
\hline & 4 & 0.0 & 0.0 & 0.0 & 0.0 & 7.0 & 4.6 & 0.0 & 2.4 & 3.1 & 2.8 & 2.7 & 3.1 \\
\hline & 5 & 0.0 & 0.0 & 0.0 & 2.3 & 2.3 & 3.1 & 4.0 & 2.4 & 2.9 & 2.7 & 2.7 & 3.0 \\
\hline & 6 & 29.5 & 24.1 & 25.0 & 25.6 & 4.7 & 0.0 & 0.0 & 0.0 & 2.8 & 2.6 & 2.6 & 2.9 \\
\hline & 7 & 31.8 & 27.6 & 41.1 & 44.2 & 4.7 & 3.1 & 0.0 & 2.4 & 1.8 & 2.0 & 1.9 & 2.1 \\
\hline & 8 & 27.3 & 17.2 & 17.9 & 16.3 & 2.3 & 3.1 & 4.0 & 0.0 & 1.2 & 1.4 & 1.1 & 1.1 \\
\hline & 9 & 11.4 & 20.7 & 12.5 & 9.3 & 0.0 & 1.5 & 0.0 & 0.0 & 0.8 & 1.1 & 0.9 & 1.0 \\
\hline & 10 & 0.0 & 10.3 & 3.6 & 2.3 & 0.0 & 0.0 & 0.0 & 4.9 & 0.7 & 0.8 & 0.8 & 0.9 \\
\hline \multirow[t]{2}{*}{$3+$} & 1 & 0.0 & 0.0 & 0.0 & 0.0 & 9.3 & 4.6 & 4.0 & 4.9 & 2.6 & 2.5 & 2.5 & 2.9 \\
\hline & 2 & 0.0 & 0.0 & 0.0 & 0.0 & 2.3 & 4.6 & 0.0 & 14.6 & 2.3 & 2.4 & 2.4 & 2.7 \\
\hline
\end{tabular}

${ }^{1} \mathrm{LFC}=$ low forage control, LFS $=$ low forage select, HFC $=$ high forage control, and HFS = high forage select. Select line was selected for increased milk fat plus protein production.

${ }^{2}$ Within-calving intervals of $60 \mathrm{~d}$ in each lactation.

than 3 lactations can be moved off the experiment. The herd calving and culling data as incorporated into the Markov chain are therefore performance characteristics of the cows in each production system and exclude voluntary culling (before lactation 4) for reasons dictated by the requirements of the herd manager, as would be found in commercial herd data. Therefore, due to the experimental protocol, cows that were culled before lactation 4 were assumed culled for involuntary reasons. Reasons for involuntary culling within the herd would typically be due to a reproductive problem, foot/leg injury, udder health including poor yield and high SCC, death, or abortion.

\section{LCA}

Resource inputs required for the production of raw milk to the farm-gate, described below, were allocated to each production system based on the herd structure reflected in the Markov chain long-run (steady) state vector. A partial LCA was carried out to describe $\mathrm{CO}_{2^{-}}$ eq. emissions and land use (on-farm and for bought-in feed) associated with each production system over a year. The effect from the production of agri-chemicals, seed, lime (and its application), and capital items were not included because these resources were either of low impact or did not vary with production system within 
the farm. Such simplifying assumptions were also made by Cederberg and Mattsson (2000) and Thomassen et al. (2008) for seed and capital items. The functional unit as defined by Guinée et al. (2002) was "1 kg of ECM leaving the farm-gate." To maintain consistency with other dairy system studies, the kilograms of $\mathrm{CO}_{2^{-}}$ eq. emissions for a 100-yr time horizon was calculated using conversion factors from $\mathrm{CH}_{4}$ and $\mathrm{N}_{2} \mathrm{O}$ to $\mathrm{CO}_{2}$ of 21 and 310, respectively, and were expressed per kilogram of ECM and per hectare (Cederberg and Mattsson, 2000; Casey and Holden, 2005; Thomassen et al., 2008, Basset-Mens et al., 2009). The sources of $\mathrm{CO}_{2}$-eq. emissions were from enteric fermentation, manure and soils (from leaching, runoff, atmospheric deposition of nitrogen from $\mathrm{NO}_{\mathrm{x}}$ and $\mathrm{NH}_{3}$, and biological fixation of nitrogen), on-farm energy use (electricity and fuel), bought-in synthetic fertilizer, and concentrate feed (Figure 1).

\section{$\mathrm{CO}_{2}$-Eq. Emissions and Land Use Predictions}

Emissions of $\mathrm{CH}_{4}, \mathrm{~N}_{2} \mathrm{O}$, and $\mathrm{CO}_{2}$ were determined as well as the total land area required to meet the animals' feed requirements. Production of $\mathrm{CH}_{4}$ included both enteric fermentation and emissions from manure. The following equation by Mills et al. (2009) was used to estimate enteric fermentation emissions from DM intake and GE intake:

$$
\begin{aligned}
\mathrm{CH}_{4}(\mathrm{MJ} / \mathrm{d}) & =(7.16-0.101 \times \mathrm{kg} \text { of DM intake }) / \\
& 100 \times \text { MJ of GE intake. }
\end{aligned}
$$

This equation was identified in a previous study (Bell, 2011a) as suitable for the wide range of values seen in the Langhill herd data. The IPCC (1997) Tier II methodology was used to predict daily GE intake, with the same methodology then being used to determine manure $\mathrm{CH}_{4}$ and $\mathrm{N}_{2} \mathrm{O}$ emissions (from $\mathrm{N}$ excretion). The assumptions made in the IPCC calculations are shown in Table 2. Forage crops were assumed to leave no residues on the land. The average daily DM intake of a milking herd replacement was set at 6.83 and $7.15 \mathrm{~kg} / \mathrm{d}$ for control and select genetic line animals, respectively. Both genetic lines were fed the same diet until they entered the milking herd. The DM intakes for control and select milking herd replacements were calculated using an IPCC (2006) Tier II methodology prediction equation, where estimates of DM intake were based on a dietary net energy concentration of the diet of $7.5 \mathrm{MJ} / \mathrm{kg}$ of $\mathrm{DM}$ and average $\mathrm{BW}$ of the animal. The average BW of control and select genetic line animals from birth to first calving were $285 \pm 24$ and $303 \pm 26 \mathrm{~kg}$, respectively. A previous study (Bell et al., 2011b) showed that the number of days from birth to first calving did not differ between genetic lines, but select genetic line animals had a higher growth rate and GE intake.

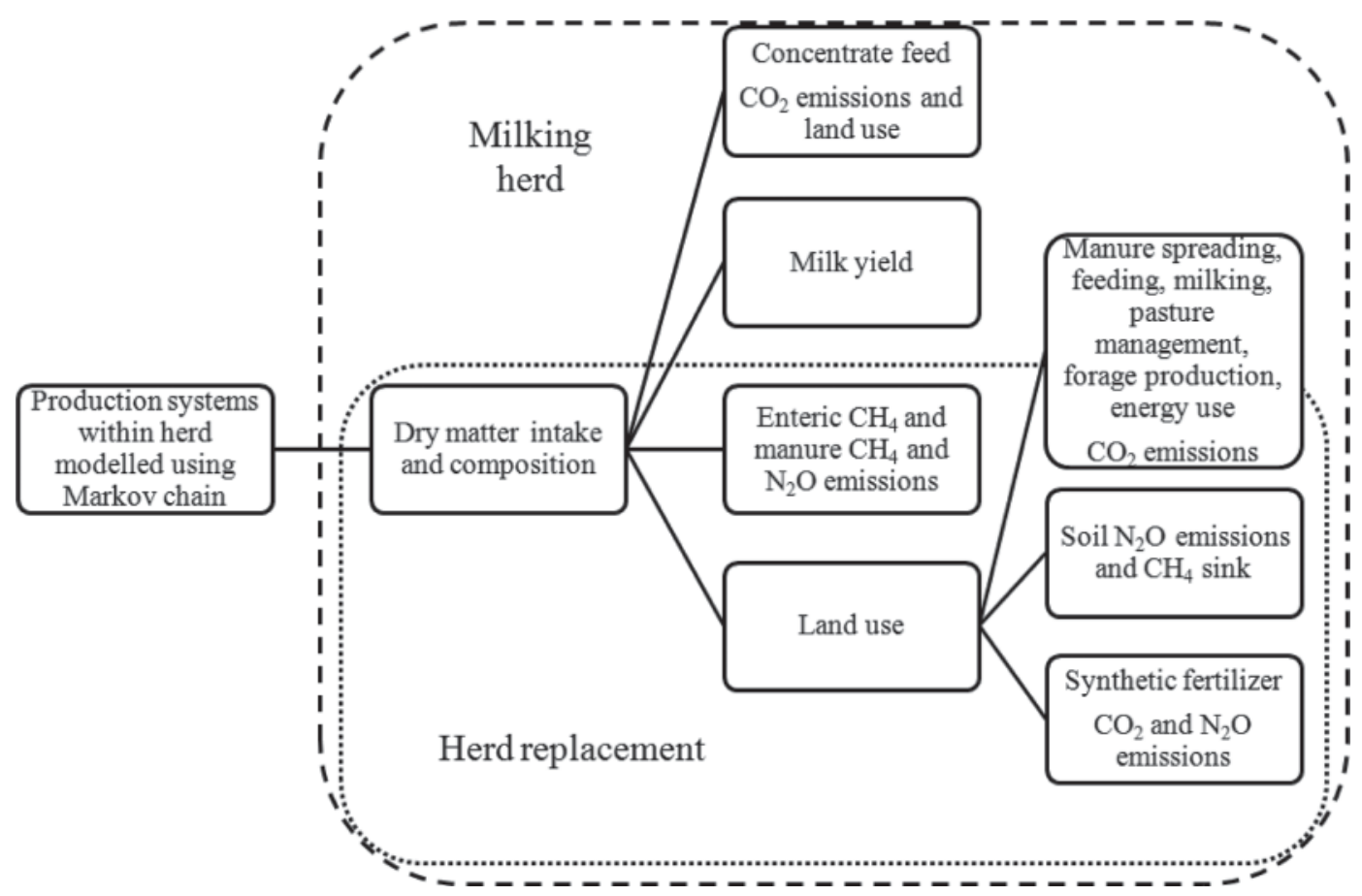

Figure 1. Sources of greenhouse gas emissions from the milking herd (-- -) and their replacement ( ..) modeled using a Markov chain and partial life cycle assessment. 
Table 2. Emission factors used to calculate the greenhouse gas emissions associated with the production of raw milk

\begin{tabular}{|c|c|}
\hline Gas/source & Equation and emission factor \\
\hline Manure conversion factor ${ }^{1}$ & $1 \%$ at pasture and $10 \%$ indoors \\
\hline Soil oxidation $^{2}$ & $2.5 \mathrm{~kg} / \mathrm{ha}$ per year for pasture and $1.5 \mathrm{~kg} / \mathrm{ha}$ per year for arable land \\
\hline Slurry & $0.001 \mathrm{~kg}$ of $\mathrm{N}_{2} \mathrm{O} / \mathrm{kg}$ of $\mathrm{N}$ \\
\hline Solid manure & $0.02 \mathrm{~kg}$ of $\mathrm{N}_{2} \mathrm{O} / \mathrm{kg}$ of $\mathrm{N}$ \\
\hline Direct soil emissions & $0.0125 \mathrm{~kg}$ of $\mathrm{N}_{2} \mathrm{O} / \mathrm{kg}$ of $\mathrm{N}$ \\
\hline Grassland fixation & $4 \mathrm{~kg}$ of $\mathrm{N} / \mathrm{ha}$ per year \\
\hline \multicolumn{2}{|l|}{ Carbon dioxide $^{3}$} \\
\hline Synthetic fertilizer & $6.847 \mathrm{~kg}$ of $\mathrm{CO}_{2}$-equivalents $\left(\mathrm{CO}_{2}\right.$-eq. $) / \mathrm{kg}$ of $\mathrm{N}$ \\
\hline Electricity & $0.042 \mathrm{~kg}$ of $\mathrm{CO}_{2}$-eq. $/ \mathrm{L}$ of milk \\
\hline Fuel & $3.8862 \mathrm{~kg}$ of $\mathrm{CO}_{2}$-eq. $/ \mathrm{L}$ \\
\hline
\end{tabular}

${ }^{1}$ UKGGI (2010).

${ }^{2}$ Boeckx and van Cleemput (2001).

${ }^{3}$ Lovett et al. (2006); it is assumed that I L of milk weighs $1.03 \mathrm{~kg}$.

Following Steinfeld et al. (2006), the amount of respired $\mathrm{CO}_{2}$ was assumed the same as the net photosynthesis of the consumed plant matter. Thus, the $\mathrm{CO}_{2}$ emissions were those associated with the production and supply of fertilizer, electricity for milk production, and fuel to the farm, and those emitted from fuel use on-farm (Table 2), as well as those from bought-in concentrate. The $\mathrm{CO}_{2}$-eq. emissions associated with concentrate feed for low and high forage diets were calculated based on $0.530 \mathrm{~kg}$ of $\mathrm{CO}_{2}$-eq. $/ \mathrm{kg}$ and 0.671 $\mathrm{kg}$ of $\mathrm{CO}_{2}$-eq. $/ \mathrm{kg}$ respectively (Table 3 ). These $\mathrm{CO}_{2}$-eq. values include emissions from processing and transport from site of production to the farm. It was assumed that soybean meal originated from Brazil and that, once in the UK, all feed components traveled $250 \mathrm{~km}$ via the processing plant in Dumfries (Scotland) to the farm (H. McClymont, Scottish Agricultural College, Dumfries, UK, personal communication). To take advantage of the $\mathrm{CO}_{2}$-eq. emission and land use values in Nielsen et al. (2003), the low and high forage diets were simplified to their main components, which were wheat, barley, sugar beet pulp, soybean meal, and rapeseed meal (Table 3). The barley component and wheat in the high forage diet were fed in the form of dark grains (a by-product of whisky distilling). Because a trivial amount of processing is required for this by-product, any additional $\mathrm{CO}_{2}$-eq. emissions were assumed to be zero. The high forage diet consisted entirely of feed not suitable for human consumption, in the form of byproducts and pasture, whereas the concentrate feed in the low forage diet was $31 \%$ wheat grain per kilogram of DM, and may well have been suitable for humans.

The area of land required by each system depended on the forage intake (pasture, grass silage, maize silage, and ammonia-treated, whole-crop wheat silage) requirement of the milking cow and its replacement, as well as that associated with bought-in concentrate feed as discussed above (obtained from Nielsen et al., 2003; Table 3). Land use was expressed in hectares per animal. The yield, fertilizer, and slurry application rate

Table 3. The carbon dioxide equivalent $\left(\mathrm{CO}_{2}\right.$-eq. $)$ emissions and land use associated with $1 \mathrm{~kg}$ of bought-in concentrate feed for low and high forage $\operatorname{diets}^{1}$

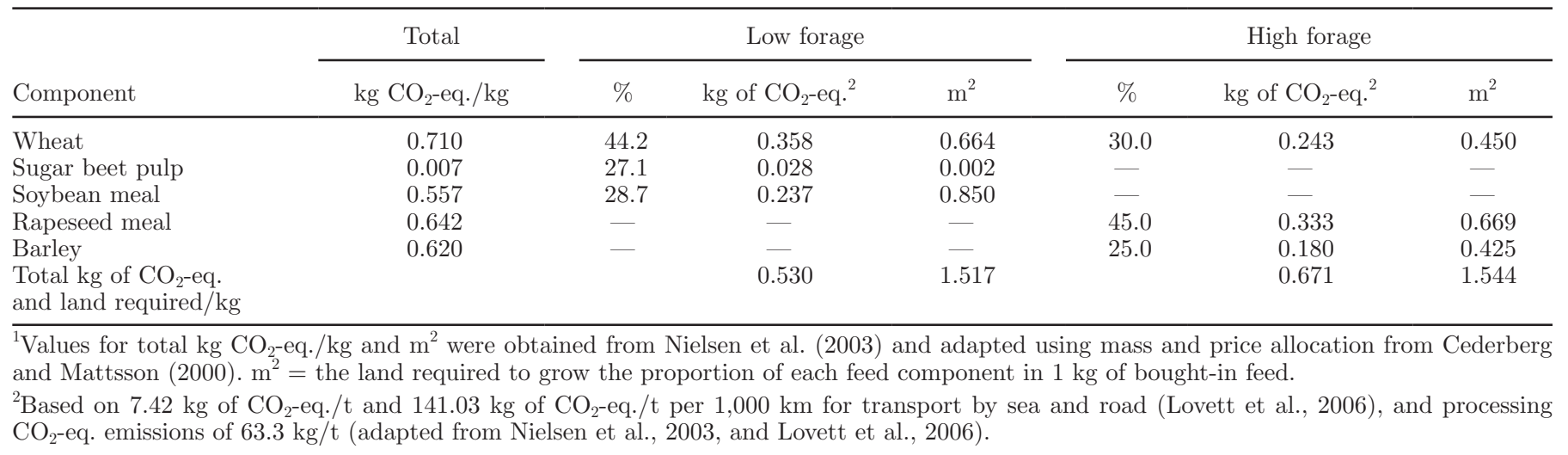


associated with forage production per hectare were, respectively, $10 \mathrm{t}$ of $\mathrm{DM}, 150 \mathrm{~kg}$ of $\mathrm{N}$, and $90 \mathrm{~m}^{3}$ for grass silage; $10.2 \mathrm{t}$ of $\mathrm{DM}, 0 \mathrm{~kg}$ of $\mathrm{N}$, and $45 \mathrm{~m}^{3}$ for maize silage; $11 \mathrm{t}$ of $\mathrm{DM}, 0 \mathrm{~kg}$ of $\mathrm{N}$, and $30 \mathrm{~m}^{3}$ for ammonia-treated wheat silage; and $10 \mathrm{t}$ of DM, $150 \mathrm{~kg}$ of $\mathrm{N}$, and $90 \mathrm{~m}^{3}$ for pasture (H. McClymont, Scottish Agricultural College, Dumfries, UK, personal communication). Land used for forage can also act as a $\mathrm{CH}_{4}$ sink, as $\mathrm{CH}_{4}$ is oxidized within aerobic soils (Boeckx and van Cleemput, 2001) at rates shown in Table 2. Fuel use was assumed to be $0.22 \mathrm{~L} /$ ha (pasture, arable management), $0.003 \mathrm{~L} / \mathrm{t}$ (slurry application), and 0.8 L/t (feeding; Lovett et al., 2006).

\section{Records and Analysis}

Data were obtained from 5,658 records from 458 cows during the study period, of which 1,479, 1,288, 1,516, and 1,375 were for LFC, LFS, HFC, and HFS cows, respectively. Each record was an average over a stage interval of $60 \mathrm{~d}$. Predicted means for the traits of interest were obtained using a linear mixed model. The data were analyzed using Genstat Version 11.1 (Lawes Agricultural Trust, 2009) and REML. Cow identity was added as a random effect to allow for covariance between subsequent lactations of the same cow. Cow BW was also added as a regression effect (excluded from the BW model) as shown below:

$$
\begin{aligned}
Y_{i j k l m n} & =\mu+L_{i}+S_{j}+F_{k} \times G_{l}+Y r_{m}+M_{n} \\
& +C_{i j k l m n}+\beta(B W)_{i j k l m n}+E_{i j k l m n},
\end{aligned}
$$

where $Y_{i j k l m n}=$ daily DM intake, daily GE intake, dietary CP, daily ECM yield, milk fat content, milk protein content, $\mathrm{N}$ excretion rate, $\mathrm{BW}$, calving interval length, and risk of involuntary culling; $\mu=$ overall mean; $L_{i}=$ fixed effect of lactation number $(1,2,3$, and $3+) ; S_{j}=$ fixed effect of state (1 to 10 states of stage intervals of $60 \mathrm{~d}$ over the lactation); $F_{k}=$ fixed effect of feeding system (low forage or high forage); $G_{l}=$ fixed effect of genetic line (control or select); $Y r_{m}=$ fixed effect of year of calving; $M_{n}=$ fixed effect of month of calving; $C_{i j k l m n}=$ random effect of cow; $\beta(B W)_{i j k l m n}=$ regression effect of cow $\mathrm{BW}$; and $E_{i j k l m n}=$ random error term.

Fixed effects of lactation number (before lactation 4) and feeding system $\times$ genetic lines were used to model for the risk of involuntary culling. Predicted mean DM intake, GE intake, ECM yield, and $\mathrm{N}$ excretion rate were obtained from the interaction between lactation number, state, and feeding system $\times$ genetic lines. Predicted mean calving interval lengths were obtained from the interaction between lactation number and state.
The predicted mean values for DM intake, GE intake, ECM yield, and N excretion were modeled across states using a quadratic polynomial, because predicted means for some production systems toward later states of a lactation were missing. The shape of the polynomial curve for each trait was not adjusted.

\section{Improved Efficiencies of Production}

The sensitivities of the $\mathrm{CO}_{2}$-eq. emissions and land use per kilogram of ECM and $\mathrm{CO}_{2}$-eq. emissions per hectare associated with each production system within the herd were assessed by a phenotypic standard deviation improvement of 4 traits (representing production and fitness traits), as well as the proportion associated with any genetic improvement. A change of 1 phenotypic standard deviation unit in each of the chosen traits was chosen as the fairest basis on which to evaluate the impact on $\mathrm{CO}_{2}$-eq. emissions and land use of changes effected by any means. A change of 1 genetic standard deviation unit is the equivalent basis on which to compare the effect of changes brought about as a result of selection. The 4 traits and their heritabilities obtained from previous studies on the Langhill herd were daily DM intake (average of 0.40 from Veerkamp et al., 1995, and Veerkamp and Brotherstone, 1997), daily ECM (average of 0.395 from Veerkamp et al., 1995 and Veerkamp and Brotherstone, 1997), calving interval (0.09 from Pryce et al., 1999), and risk of involuntary culling during lactation 1,2 , or 3 (0.026 from Veerkamp et al., 2001) based on national data for all cows culled. The herd phenotypic standard deviations $\left(\sigma_{\mathrm{p}}\right)$ for each trait across lactations, states, and production systems were determined using the linear mixed model above, with the genetic standard deviation $\left(\sigma_{\mathrm{a}}\right)$ being derived by the formula

$$
\sigma_{\mathrm{a}}=\sigma_{\mathrm{p}} \times \mathrm{h},
$$

where $\mathrm{h}$ is the square root of the heritability. The traits for which a standard deviation change was modeled were (1) daily DM intake $\left(\mathrm{h}^{2}=0.40\right)$ while maintaining the same ECM yield, representing an improvement in feed utilization efficiency; (2) ECM yield $\left(h^{2}=0.395\right)$ while maintaining the same level of daily DM intake, representing an improvement in productivity; (3) calving interval length $\left(\mathrm{h}^{2}=0.09\right)$ to have a higher proportion of cows with a calving interval of between 361 and $420 \mathrm{~d}(\mathrm{~s}=7)$ of each lactation rather than later than $420 \mathrm{~d}(\mathrm{~s}=8,9$, or 10), representing an improvement in fertility; and (4) probability of being culled during lactation 1,2 , or $3\left(\mathrm{~h}^{2}=0.026\right)$, representing a reduction in involuntary culling and improved survival to lactations $3+$. 
A phenotypic or genetic standard deviation change in predicted mean daily DM intakes and ECM yields was made to modeled values across lactation numbers, states, and production systems before the Markov chain long-run state probabilities were applied. Changes to calving and culling data were applied to input data to the Markov chain before obtaining the long-run state probabilities. Weighted average calving interval lengths were obtained for each lactation and production system, based on the herd's predicted mean calving interval length for each state within lactation and the percentage of cows calving during each state. The weighted average calving interval was then changed by a standard deviation (1 SD) to create a new average, represented by an equal adjustment to the percentage of cows calving during states later than $420 \mathrm{~d}$ ( $\mathrm{s}=8$, 9 , or 10$)$ to between 361 and $420 \mathrm{~d}(\mathrm{~s}=7)$, reflecting better fertility performance within the herd. The phenotypic or genetic standard deviation change in probability of involuntary culling was applied to a lactation $(1,2$, or 3$)$ due to the low number of cows culled in each state. A 1-SD improvement in herd feed utilization efficiency, ECM yield, calving interval length, and involuntary culling was assessed for its effect on the $\mathrm{CO}_{2}$-eq. emissions from all sources. The $\mathrm{CO}_{2}$-eq. emissions per kilogram of ECM and per hectare from each source associated with the production systems studied were also determined.

\section{RESULTS}

\section{Differences Between Production Systems}

Table 4 shows the difference in production values of milking herd animals and important input variables from farm data for estimating the $\mathrm{CO}_{2}$-eq. emissions and land use associated with the systems evaluated in this study. The nongrazing LFS cows yielded the most ECM and excreted more kilograms of $\mathrm{N}$ per day compared with cows on the other production systems studied (both $P<0.05$ ). Cows on a nongrazing low forage system and those of the select genetic line had a significantly higher DM intake, GE intake, daily ECM yield, $\mathrm{N}$ excretion rate, and $\mathrm{BW}$ compared with high forage or control genetic line animals, respectively (all $P<0.001$ ). Select genetic line animals had, on average, higher fat and protein contents in their milk compared with control line animals (both $P<0.001$ ). Animals fed high forage diets had a significantly higher milk fat content $(P<0.001)$ and calving interval $(P<0.01)$ compared with those fed a low forage diet. The risk of involuntary culling during lactations 1,2 , or 3 did not differ between production systems. However, Table 4 does show, on average, a higher tendency for HFC cows and a lower tendency for HFS cows to be culled for involuntary reasons during lactations 1,2 , or 3 compared with the other production systems studied.

The herd phenotypic standard deviations used to assess changes in daily DM intake (feed efficiency), ECM yield, calving interval length, and involuntary culling were $2.2 \mathrm{~kg} / \mathrm{d}, 5.4 \mathrm{~kg} / \mathrm{d}, 18.1 \mathrm{~d}$, and $6.2 \%$, respectively. The corresponding genetic standard deviations used to assess a change in each of the 4 traits were $1.4 \mathrm{~kg} / \mathrm{d}, 3.4$ $\mathrm{kg} / \mathrm{d}, 5.4 \mathrm{~d}$, and $1.0 \%$, respectively. The Markov chain results highlight that the herd structure was skewed toward lactation 1 cows and within lactation toward those in the earlier states of the calving interval, with a steep drop beyond state 7 (420 d; Table 1). Distinctions between production systems were comparatively small, although the LFC group did have a higher proportion of the herd in more productive states, except in lactation 4. The nongrazing LFS system had the highest overall $\mathrm{CO}_{2}$-eq. emissions of all 4 systems. The total emissions per year and land use per cow for each production system were $10,934 \mathrm{~kg}$ of $\mathrm{CO}_{2}$-eq. and 0.69 ha, $11,894 \mathrm{~kg}$ of $\mathrm{CO}_{2}$-eq. and $0.74 \mathrm{ha}, 10,446 \mathrm{~kg}$ of $\mathrm{CO}_{2}$-eq. and $0.94 \mathrm{ha}$, and $11,301 \mathrm{~kg}$ of $\mathrm{CO}_{2}$-eq. and 1.00 ha for LFC, LFS, HFC, and HFS systems, respectively.

The LFS production system had the lowest $\mathrm{CO}_{2}$-eq. emissions per kilogram of ECM by at least $11 \%$ (Figure 2 ). The largest contribution to the $\mathrm{CO}_{2}$-eq. emissions per kilogram of ECM and hectare across production systems came from enteric fermentation $(34 \%)$, followed by manure and soils (32\%). On-farm energy use (8\%), synthetic fertilizer (9 and 16\% for low forage and high forage diets, respectively), and concentrate feed (17 and $10 \%$ for low forage and high forage diets, respectively) made lesser but still important contributions (Figures 2 and 3). The nongrazing low forage system resulted in $\mathrm{CO}_{2}$-eq. emissions per hectare at least $30 \%$ higher, on average, than the high forage feeding system, in which cows grazed during the summer months (Figure 3). However, low forage systems required less land per kilogram of ECM (averaging 0.70 and $1.13 \mathrm{~m}^{2} / \mathrm{kg}$ of ECM, respectively). Higher annual ECM production per hectare was achieved from low forage than from high forage systems $(14,391$ and $8,938 \mathrm{~kg} / \mathrm{ha}$, respectively). The LFS system used at least $13 \%$ less land per kilogram of ECM than the other production systems studied.

\section{Improved Efficiencies of Production}

Figure 4 shows that a 1-SD improvement in feed utilization efficiency would be the only trait of the 4 traits studied that would reduce the average $\mathrm{CO}_{2}$-eq. emissions of the herd. A reduction of $6.5 \%$ in $\mathrm{CO}_{2}$-eq. emissions per year $(4.1 \%$ per genetic standard devia- 


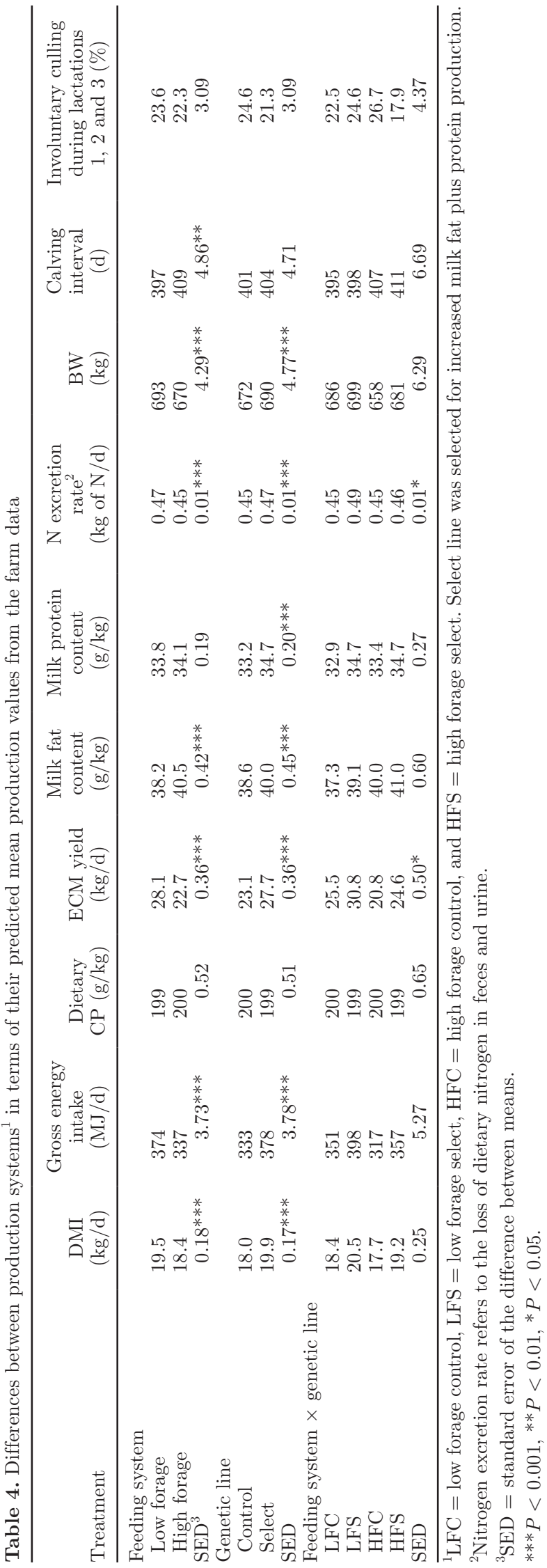

tion change) was seen in the average overall $\mathrm{CO}_{2}$-eq. emissions of the herd, as well as a reduction in the need for bought-in fertilizer (7.3\% phenotypic and $4.6 \%$ genetic) and concentrate feed (11.3\% phenotypic and $7.2 \%$ genetic). Even though improvements in average ECM yield, calving interval length, and involuntary culling did not reduce the average $\mathrm{CO}_{2}$-eq. emissions of the herd, and indeed caused a slight overall increase (Figure 4), reductions in system emissions per kilogram of ECM are possible (Figure 5). Improving a cow's feed utilization efficiency while maintaining the same level of milk production is also the best way of decreasing the land use required per cow compared with the other traits studied (Figure 6), with a 1 phenotypic standard deviation improvement in feed utilization efficiency resulting in a $6.7 \%$ reduction in land use per cow $(4.2 \%$ reduction per genetic standard deviation change).

Improving the utilization of feed within a system by 1 phenotypic standard deviation was an effective way to reduce the $\mathrm{CO}_{2}$-eq. emissions per kilogram of ECM (Figure 5), with a 6.0 to $6.9 \%$ reduction in $\mathrm{CO}_{2}$-eq. emissions per kilogram of ECM across all systems (3.8 to $4.4 \%$ per genetic standard deviation change). Figure 5 also shows that the greatest reduction in overall $\mathrm{CO}_{2}$-eq. emissions per kilogram of ECM compared with an equivalent improvement in other traits studied was from a 1-SD increase in ECM yield, with the largest reductions being in the least productive HFC system. Reductions ranged from 14.3 to $17.0 \%$ (phenotypic) and from 9.5 to $13.2 \%$ (genetic). Reducing the herd's average calving interval by 1 SD had a small effect on reducing the $\mathrm{CO}_{2}$-eq. emissions per kilogram of ECM of the production systems studied, with the LFC system showing the largest reduction of about $0.8 \%$ (about $0.2 \%$ per genetic standard deviation change). Nor would reducing the risk of involuntary culling have a significant effect on reducing the $\mathrm{CO}_{2}$-eq. emissions per kilogram of ECM within each production system, with select genetic line animals showing the main reductions of about 0.13 and $0.16 \%$ for low and high forage animals respectively.

Reducing the daily DM intake of cows on a high forage diet while maintaining the same ECM yield led to an increase of $0.8 \%$ in $\mathrm{CO}_{2}$-eq. emissions per hectare, whereas cows subjected to the same treatment but on a low forage diet showed a similar reduction (Figure 7). This effect was due to the influence of constraining milk production while changing feed intake. Improving the ECM yield of cows resulted in an increase in $\mathrm{CO}_{2}$-eq. emissions per hectare across all systems. A similar improvement in calving interval length showed small reductions in high forage-fed animals of 0.16 and $0.25 \%$ for control and select animals, respectively, but only $0.02 \%$ in control genetic line animals as a result 


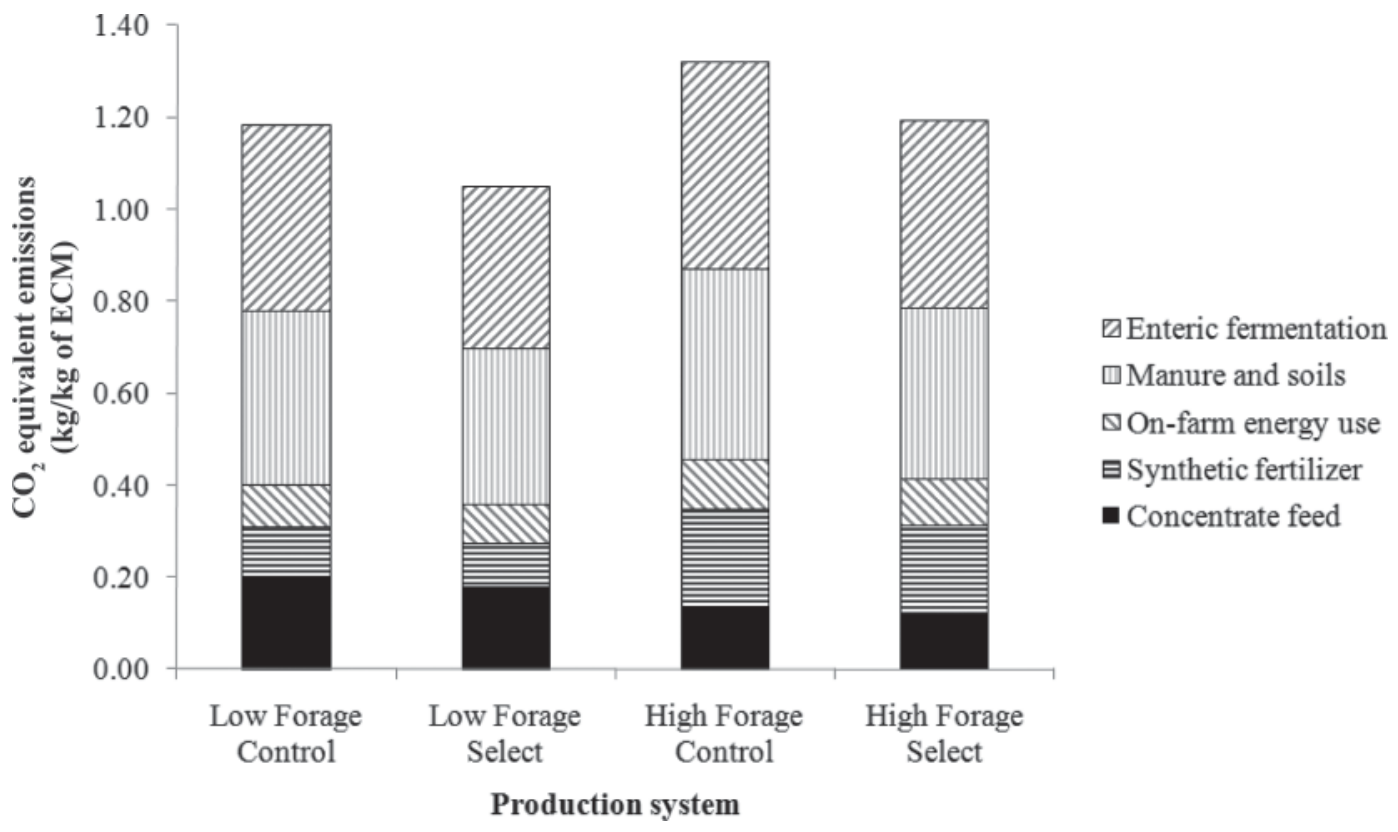

Figure 2. Carbon dioxide-equivalent emissions ( $\mathrm{kg}$ of $\mathrm{CO}_{2}$-eq./ $\mathrm{kg}$ of $\mathrm{ECM}$ ) associated with each production system studied and the relative contribution from enteric fermentation, manure and soils, on-farm energy use, synthetic fertilizer, and concentrate feed.

of reduced involuntary culling (with little or no genetic improvement).

Land use requirements per kilogram of ECM were also reduced within all production systems studied but more by an improvement in ECM than by feed utilization efficiency (Figure 8). The largest reduction in land use per kilogram of ECM by a 1-SD increase in ECM yield was seen in the least productive HFC system $(20.0 \%$ reduction with $14.0 \%$ per genetic standard deviation change). In the same system, improved feed utilization efficiency resulted in a $7.7 \%$ reduction (with $4.9 \%$ per genetic standard deviation change). In

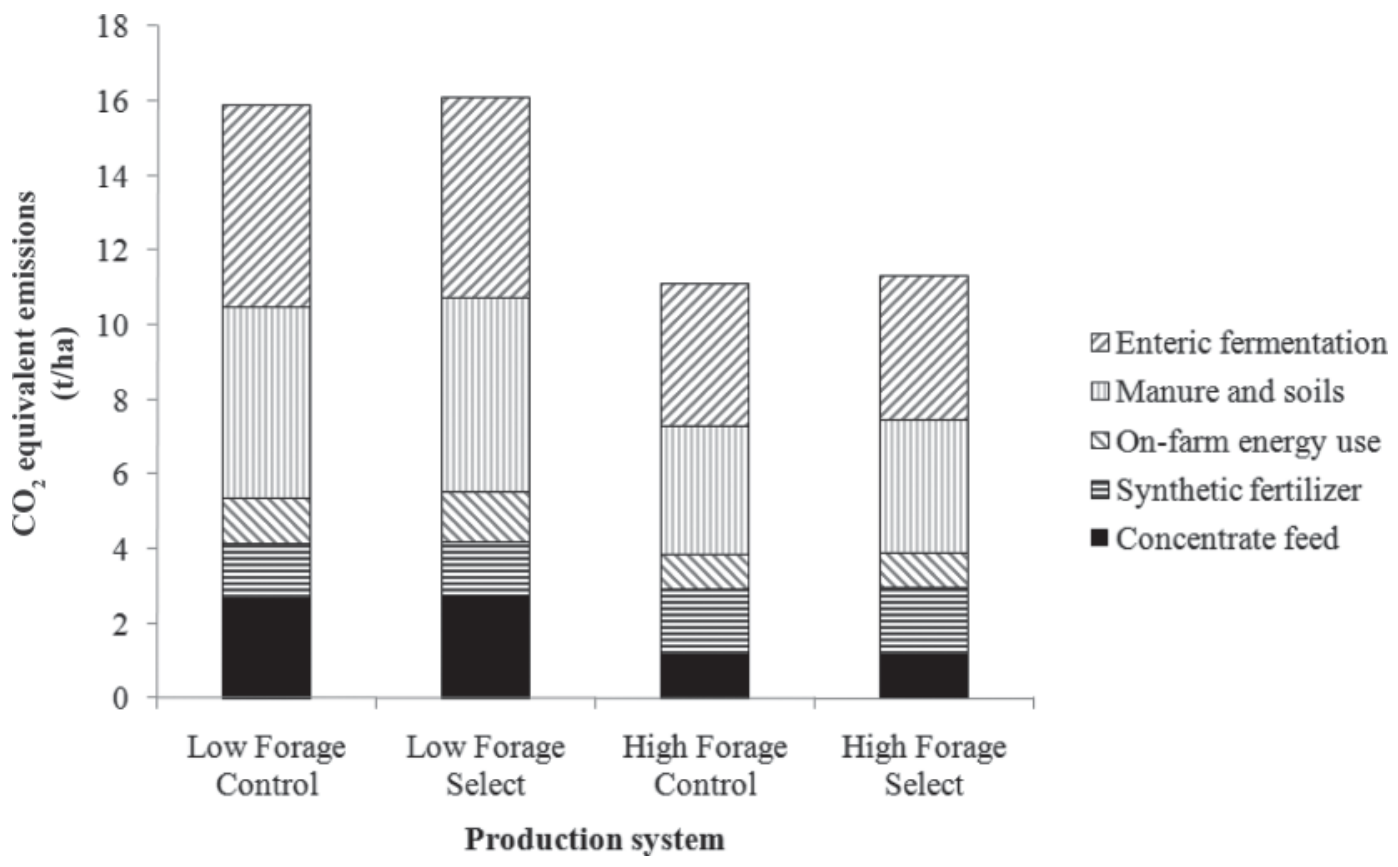

Figure 3. Carbon dioxide-equivalent emissions ( $\mathrm{t}$ of $\mathrm{CO}_{2}$-eq./ha) associated with each production system studied and the relative contribution from enteric fermentation, manure and soils, on-farm energy use, synthetic fertilizer, and concentrate feed. 

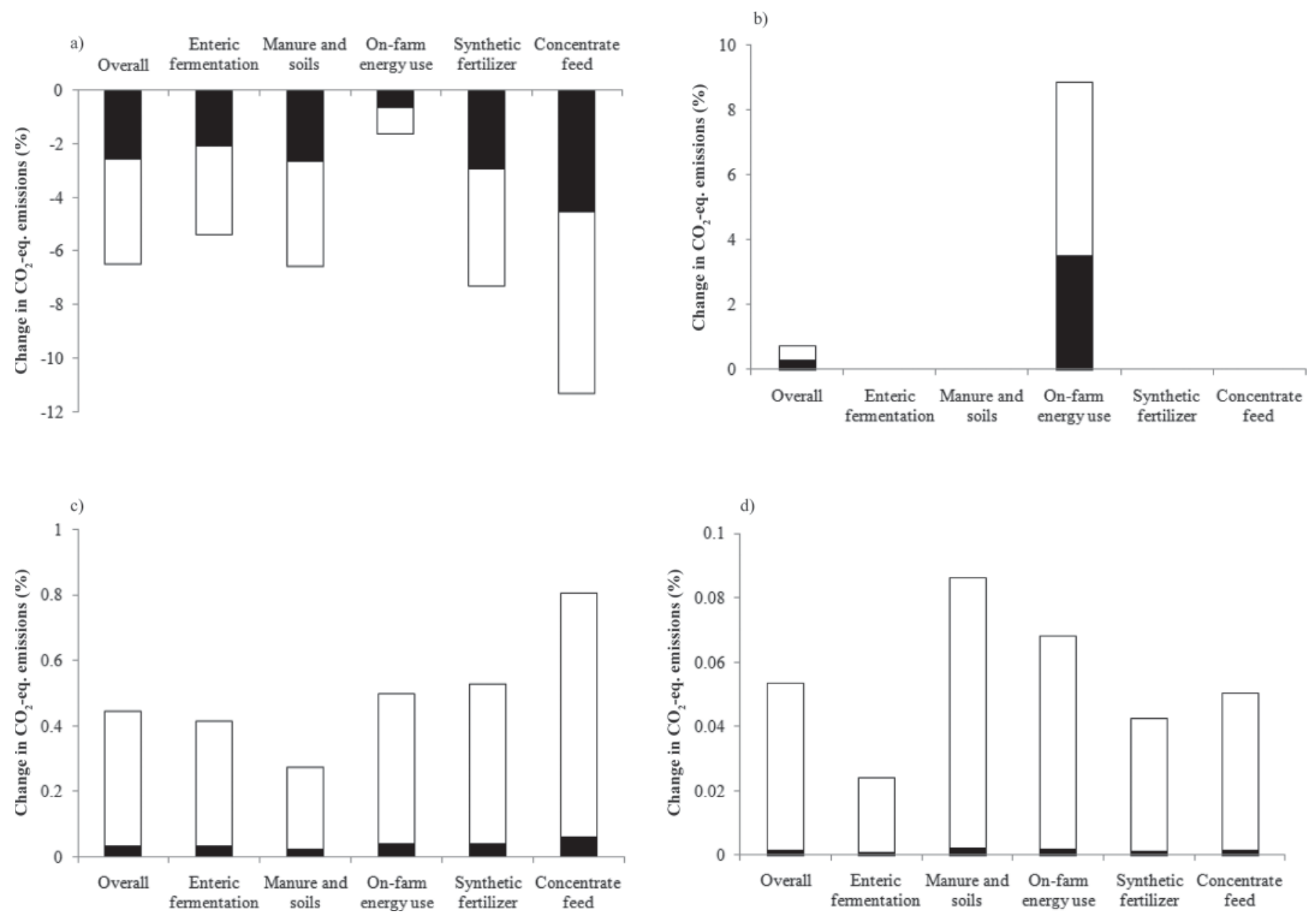

Figure 4. Percentage change in herd carbon dioxide equivalent $\left(\mathrm{CO}_{2}\right.$-eq.) emissions associated with all sources (overall), enteric fermentation, manure and soils, on-farm energy use, synthetic fertilizer, and concentrate feed sources as a result of a 1 phenotypic $(\square)$ and genetic $(\boldsymbol{\square})$ standard deviation improvement in a) feed utilization efficiency, b) ECM yield, c) calving interval, and d) involuntary culling.

comparison, the most productive LFS system had the smallest, albeit still significant, percentage reduction in land use per kilogram of ECM of $14.8 \%$ (with $9.9 \%$ per genetic standard deviation change) and also with regard to feed utilization efficiency at $5.4 \%$ (with $3.4 \%$ per genetic standard deviation change). A similar level of improvement in calving interval length and risk of involuntary culling had less of an effect on land use per kilogram of ECM than feed utilization efficiency and ECM yield changes, with LFC, LFS, and HFC animals showing a reduction of between 0.2 and $1.0 \%$ for an improved calving interval length, and LFS and HFS animals showing 0.17 and $0.23 \%$ reductions, respectively, as a result of an improvement in the risk of involuntary culling.

\section{DISCUSSION}

The dairy production systems within the Langhill herd evaluated in this study were designed to repre- sent a range of dairy systems. Dairy systems with cows suited to high inputs and with a high genetic potential for milk production have become increasingly common. Consequently, an increase in the adoption of nongrazing systems has occurred (Haskell et al., 2006), so cows can meet their energy requirements using high-energy-dense concentrate feeds with associated increased digestibility and rumen fermentation rates. Cows with North American Holstein-Friesian genes have been found to show a better response in milk yield to concentrate feed in their diet compared with New Zealand Holstein-Friesian cows, which have been selected for higher milk yield performance from pasture (Dillon, 2006). O'Brien et al. (2010) found that New Zealand Holstein-Friesian cows managed with a high stocking rate were more suited to a low input pasture-based system, whereby they were more profitable and with lower GHG emissions than cows with North American Holstein genes on this type of system. However, pasture can vary much more in 

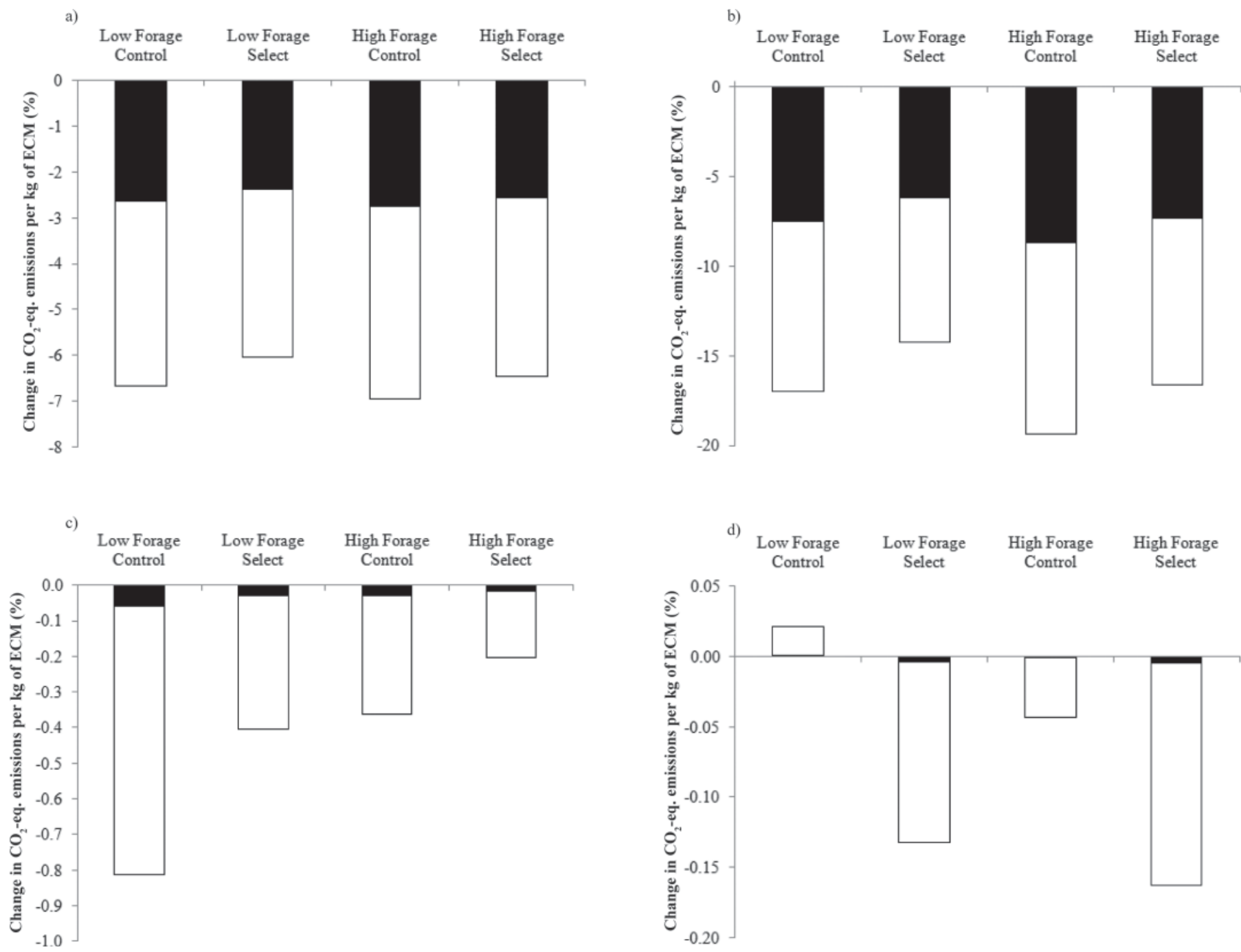

Figure 5. Percentage change in system carbon dioxide equivalent $\left(\mathrm{CO}_{2}\right.$-eq.) emissions per kilogram of ECM as a result of a 1 phenotypic ( $\square$ ) and genetic ( $\mathbf{\square}$ ) standard deviation improvement in a) feed utilization efficiency, b) ECM yield, c) calving interval, and d) involuntary culling for each production system studied.

quality compared with a blended concentrate feed or even conserved forages used in a TMR. A poorer quality food can impair energy intake and potential milk yield of the animal, as can the cow's inability to achieve desired herbage intake at pasture (Dillon et al., 2006; Dillon, 2006). Herbage can also vary in its availability but when available it is generally more affordable than blended concentrate feed. Therefore, it is important to consider the effect not only in $\mathrm{CO}_{2}$-eq. emissions per unit product (per kg ECM) but also per hectare of land required for feed.

On average, the nongrazing, low forage fed cows in this study, predominantly of North American Holstein genetic background, produced $15 \%$ more milk each day per kilogram of DM intake and required $26 \%$ less land for forage and concentrate feed than cows on systems utilizing pasture. The higher productivity associated with a nongrazing system in the present study meant higher $\mathrm{CO}_{2}$-eq. emissions per hectare compared with other production systems in this and other studies on intensive dairy systems (Table 5). The differences between studies in their reported $\mathrm{CO}_{2}$-eq. emissions per kilogram of ECM and per hectare and land use per kilogram of ECM reflect the variation in intensive systems evaluated. Basset-Mens et al. (2009) found that $\mathrm{CO}_{2^{-}}$ eq. emissions and land use per kilogram of ECM for the average New Zealand Holstein-Friesian dairy system, presented in Table 5, could be further reduced to 0.65 $\mathrm{kg}$ of $\mathrm{CO}_{2}$-eq. $/ \mathrm{kg}$ of ECM and $0.74 \mathrm{~m}^{2} / \mathrm{kg}$ of ECM, respectively, with lower inputs to the current HolsteinFriesian pasture-based systems typically found in New Zealand, which would result in lower values than those 


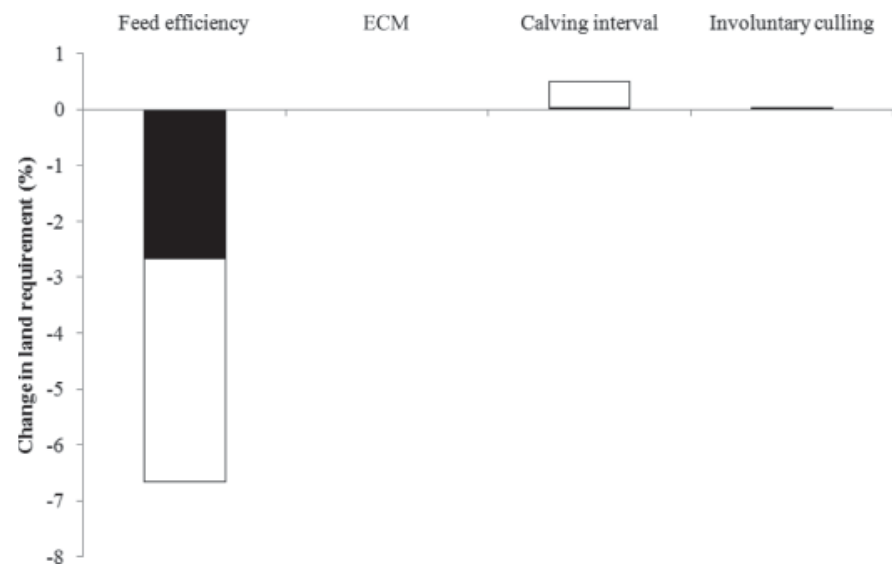

Figure 6. Percentage change in the average land area required per cow for feed as a result of a 1 phenotypic $(\square)$ and genetic $(\boldsymbol{\square})$ standard deviation improvement in feed utilization efficiency, ECM yield, calving interval, and involuntary culling.

seen in other studies. Basset-Mens et al. (2009) suggested that New Zealand's pasture-based systems could rely almost entirely on natural resources rather than bought-in farm inputs in addition to having a lower environmental impact, as mentioned above. Compared with the present study, the study by Basset-Mens et al. (2009) included capital items such as buildings and machinery, which were not included in this study as it assessed inputs that varied with the production systems within the same farming unit.

The present study showed that management and breeding for improved feed utilization would be the most effective way of reducing $\mathrm{CO}_{2}$-eq. emissions, land use, as well as $\mathrm{CO}_{2}$-eq. emissions per kilogram of ECM, and land required per kilogram of ECM of the systems studied. By improving feed use within a system, the $\mathrm{CO}_{2}$-eq. emissions associated with bought-in resources such as fertilizer and concentrate feed can be reduced by 7 and $11 \%$, respectively. Casey and Holden (2005) and Thomassen et al. (2008) found that better farm nutrient and pasture management would reduce the $\mathrm{CO}_{2}$-eq. emissions of dairy systems by minimizing the need for bought-in fertilizer and concentrate feed. In the present study, only a slight change in $\mathrm{CO}_{2}$-eq. emissions per hectare of each production system studied occurred as a result of an improvement in feed utilization efficiency, as emissions per hectare reflect the efficiencies of use of resource inputs to the farming system (i.e., on-farm energy use and synthetic fertilizer), similar to the findings of Basset-Mens et al. (2009) and O'Brien et al. (2010). Further research could assess the effect on system emissions from changes in resource inputs. A reliance on bought-in concentrate feed, which can be costly, has an additional environmental impact depending on the feed and whether it was a by-product. The cows on the low forage diet in this study may have a lower $\mathrm{CO}_{2}$-eq. emissions and land requirement per kilogram of ECM compared with cows on the high forage diet; however, the high forage diet consisted entirely of feed products that are not suitable for human consumption (pasture and by-products from the brewing and distilling industries). There is no reason why the feed used in the low forage diet fed in this study should not also be sourced from products not suitable for human consumption. It is more efficient to utilize crops that are suitable for human consumption directly rather than as a livestock product (Gill et al., 2009). In addition, by-products such as brewers grains, distillers dark grains, and draff from the brewing and distilling industries have a relatively low $\mathrm{CH}_{4}$ output as a percentage of GE compared with other feed products (Wainman et al., 1984) and represent a useful source of low $\mathrm{CO}_{2}$-eq. emission nutrients for dairy cows. The effect of feeds from different sources was not included in the analysis because more information is required before this can be included as an impact category. This study standardized the $\mathrm{CO}_{2}$-eq. emissions for concentrate components of the diets fed, whereas, in reality, distances traveled and feed components used will vary between farming systems and affect the $\mathrm{CO}_{2}$-eq. emissions associated with bought-in feed.

The present study showed that $66 \%$ of the $\mathrm{CO}_{2}$-eq. emissions from a dairy system per kilogram of ECM and hectare are from $\mathrm{CH}_{4}$ and $\mathrm{N}_{2} \mathrm{O}$ emissions, through enteric fermentation, manure, and soil sources; that is, as a result of the on-farm nutrient utilization of the animal. Yan et al. (2010) found that selecting cows with high efficiencies of energy utilization and milk productivity offers an effective way of reducing enteric $\mathrm{CH}_{4}$ emissions. Selection for increased milk fat and protein yield was previously seen to reduce dairy system $\mathrm{CH}_{4}$ emissions (Bell et al., 2010a) and non-milk nitrogen yield per kilogram of milk (Chagunda et al., 2009), even though high-milk-producing cows are associated with higher emissions per animal. Increasing the genetic capacity of the animal to produce more milk will increase total GHG emissions from a dairy system. However, $\mathrm{CO}_{2}$-eq. emissions per unit product can be reduced, as was shown by Lovett et al. (2006) and seen in this study. The reduction in $\mathrm{CO}_{2}$-eq. emissions per unit product is due to high-milk-producing cows (i.e., from the select genetic line) having a higher GE efficiency than lower milk producing cows (Wall et al., 2010), which is optimized when mature size and maximum milk production is reached (VandeHaar and St Pierre, 2006). VandeHaar and St Pierre (2006) suggest that when maximum energetic efficiency is reached, environmental waste (in the form of $\mathrm{CH}_{4}$ and nitrogen excretion) will be minimized per unit product. 
a)

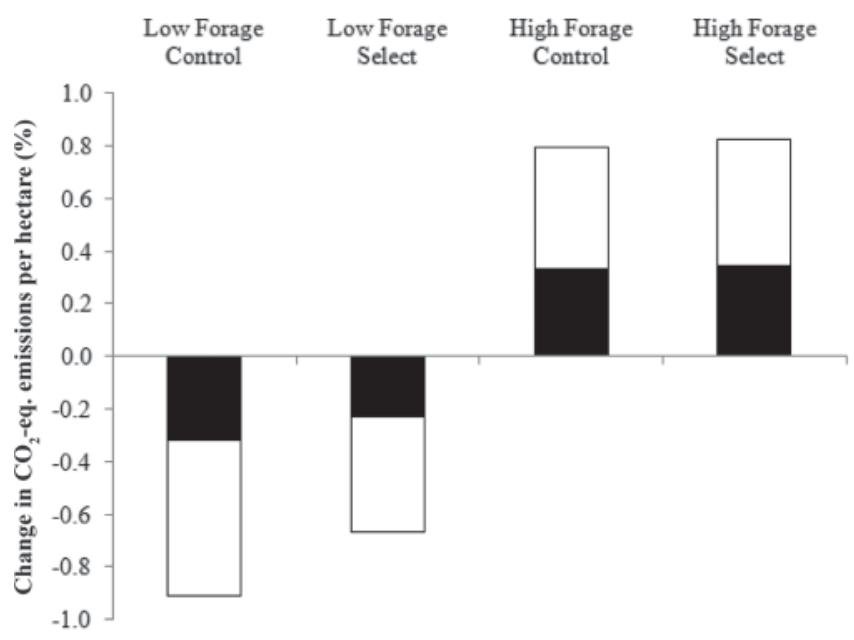

a)

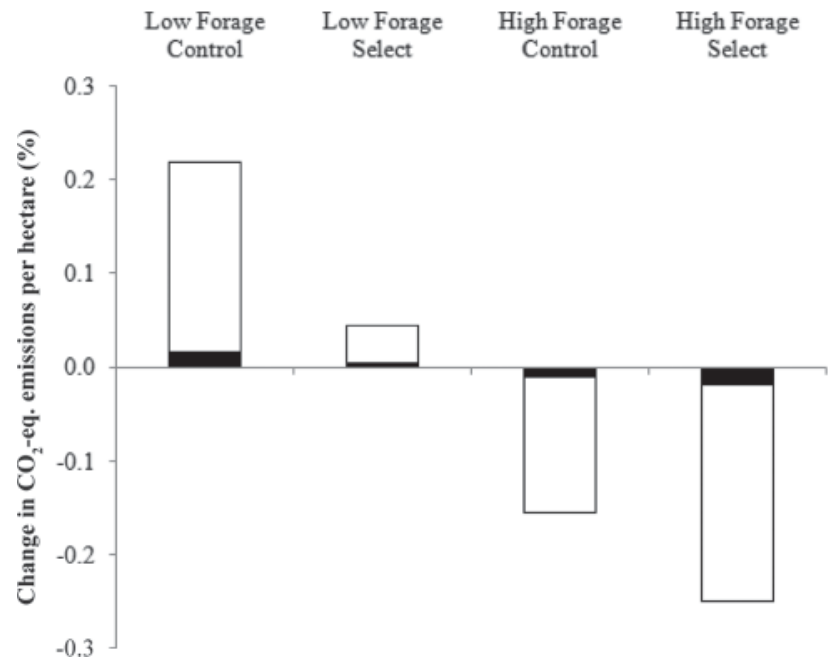

b) $\begin{array}{cccc}\begin{array}{c}\text { Low Forage } \\ \text { Control }\end{array} & \begin{array}{c}\text { Low Forage } \\ \text { Select }\end{array} & \begin{array}{c}\text { High Forage } \\ \text { Control }\end{array} & \begin{array}{c}\text { High Forage } \\ \text { Select }\end{array}\end{array}$

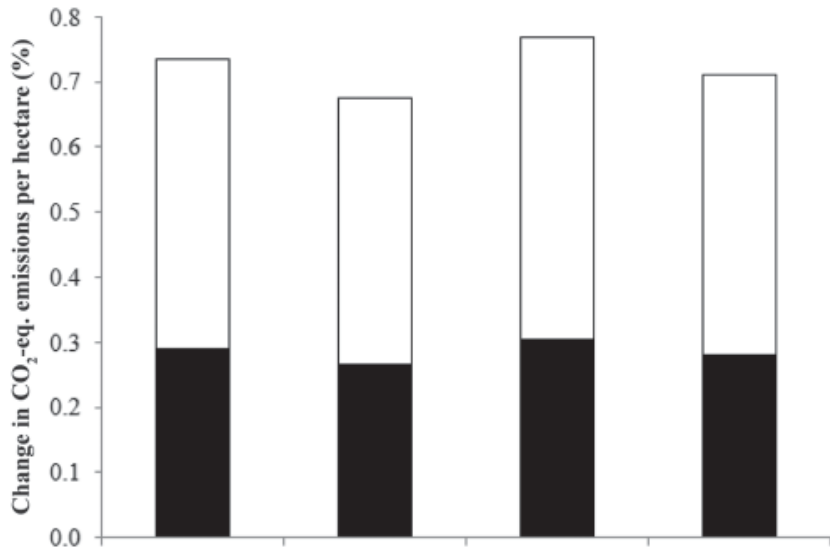

b)

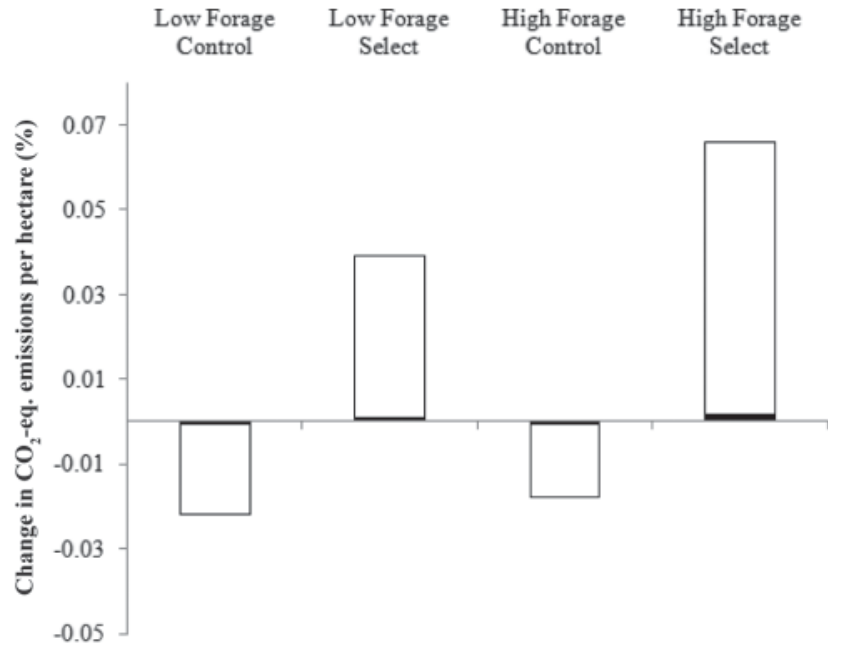

Figure 7. Percentage change in system carbon dioxide equivalent $\left(\mathrm{CO}_{2}\right.$-eq.) emissions per hectare as a result of a 1 phenotypic ( $\left.\square\right)$ and genetic (ם) standard deviation improvement in a) feed utilization efficiency, b) ECM yield, c) calving interval, and d) involuntary culling for each production system studied.

Management and breeding for increased productivity (daily ECM yield) can have a large effect on reducing the $\mathrm{CO}_{2}$-eq. emissions and land use requirement per kilogram of ECM while maintaining the same level of DM intake, albeit with a slight overall increase in the $\mathrm{CO}_{2}$-eq. emissions per hectare. As mentioned above, to maximize the genetic potential of high-milk-producing cows, diets with high energy density in the form of a TMR are usually fed in a controlled area. Selection for improvements in production efficiencies (i.e., the ratio of yield of milk to resource input) with regard to nutrient partitioning and feed intake has major potential for reducing the GHG of dairy systems (Bauman et al., 1985; Bell et al., 2010a). Also, cows with a high BW, such as the nongrazing LFS animals in this study, have been found to have a greater bite weight when eating and therefore are more efficient in their use of time spent feeding (Dillon, 2006). In addition to animal efficiencies, the housed environment offers a potential source of electricity from manure $\mathrm{CH}_{4}$ emissions, provided the manure storage area is kept gas-tight (Clemens et al., 2006). Well-established techniques such as anaerobic digestion (Cantrell et al., 2008), could capture and utilize the $\mathrm{CH}_{4}$ emissions associated with manure from a housed environment. This could offset some of $\mathrm{CO}_{2}$-eq. emissions associated with energy use and reduce the contribution of manure to GHG emissions (Clemens et al., 2006). 
Table 5. Comparison of the carbon dioxide equivalent $\left(\mathrm{CO}_{2}\right.$-eq.) emissions per kilogram of ECM yield and hectare $(\mathrm{t} / \mathrm{ha})$, and land use $\left(\mathrm{m}^{2}\right)$ per kilogram of ECM of Langhill herd production systems with other intensive dairy system studies

\begin{tabular}{lccc}
\hline & \multicolumn{2}{c}{$\mathrm{CO}_{2}$-eq. emission } & \\
\cline { 2 - 3 } Study $^{1}$ & $\begin{array}{c}\mathrm{kg} / \mathrm{kg} \\
\text { of ECM }\end{array}$ & t/ha & $\begin{array}{c}\text { Land use } \\
\left(\mathrm{m}^{2} / \mathrm{kg} \text { of ECM }\right)\end{array}$ \\
\hline Nongrazing low forage control $^{\text {Nongrazing low forage select }}$ & 1.18 & 15.9 & 0.75 \\
High forage control & 1.05 & 16.1 & 0.65 \\
High forage select & 1.32 & 11.1 & 1.19 \\
Cederberg and Mattsson (2000) & 1.19 & 11.3 & 1.06 \\
Haas et al. (2001) & 1.10 & 5.7 & - \\
Casey and Holden (2005) & 1.30 & 9.4 & 1.28 \\
Thomassen et al.(2008) & 1.51 & -1.0 & 1.05 \\
Basset-Mens et al. (2009) & 1.41 & 1.0 & - \\
\hline
\end{tabular}

${ }^{1}$ Select line was selected for increased milk fat plus protein production.
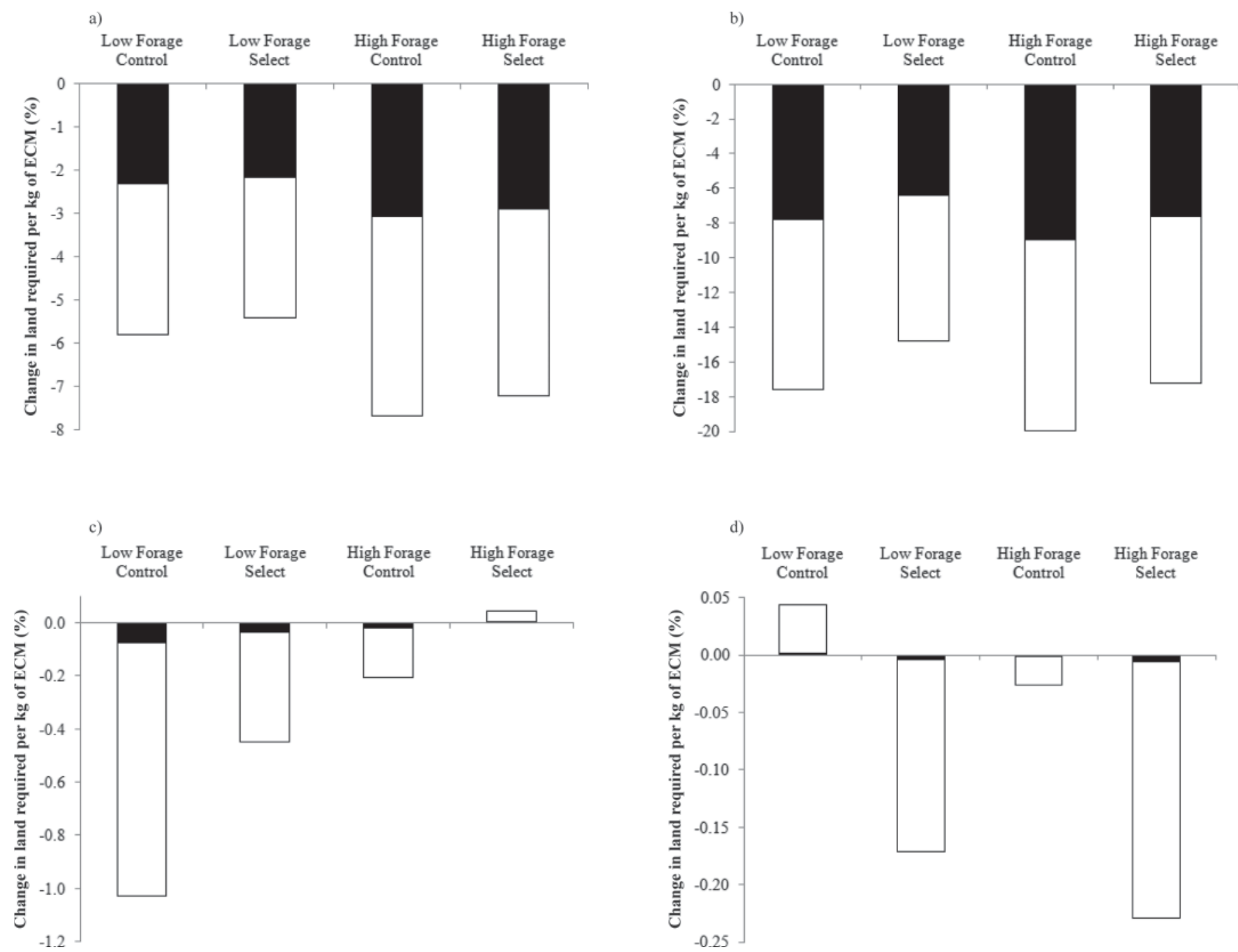

Figure 8. Percentage change in system land requirement for feed per kilogram of ECM as a result of a 1 phenotypic ( $\square$ ) and genetic ( standard deviation improvement in a) feed utilization efficiency, b) ECM yield, c) calving interval, and d) involuntary culling for each production system studied. 
Of the traits assessed in this study, increasing feed utilization efficiency and ECM yield (i.e., production traits) had more of an effect on reducing the environmental impact of the production systems evaluated compared with improvements in the fitness traits of calving interval length and risk of involuntary culling. Because of efficient production, however, healthy and fertile cows do offer savings in GHG per unit product (Garnsworthy, 2004). The results in this study associated with the risk of involuntary culling may be affected by the experimental protocol, as cows are required to be kept in the herd for at least 3 lactations unless welfare dictates that culling is necessary. In contrast to the study by Garnsworthy (2004), where a higher proportion of forage in the diet was fed with an extended lactation, the cows in this study remained on the same diet throughout their lactation and a fixed lactation curve was assumed for a 600-d calving interval. An increasing proportion of forage in the diet will increase the proportion of energy intake lost as $\mathrm{CH}_{4}$ and increase $\mathrm{CH}_{4}$ output per unit product (Bell et al., 2010a). Therefore, the large reduction in $\mathrm{CH}_{4}$ emissions reported by Garnsworthy (2004) as a result of improving fertility performance at the herd level could be higher than that achievable in practice. Cows in each production system in this study showed a slight reduction in $\mathrm{CO}_{2}$-eq. emissions per kilogram of ECM with an improvement in fertility because of more animals moving to more productive stages of the lactation.

\section{CONCLUSIONS}

Cows selected for increased milk fat and protein yield (i.e., the select genetic line) rather than to represent the UK average (i.e., the control genetic line) were not compromised in this study by their fertility performance and risk of involuntary culling while on a high or low forage diet; therefore, $\mathrm{CO}_{2}$-eq. emissions per kilogram of ECM and per hectare, as well as land use per kilogram of ECM were minimally affected compared with other traits studied. The $\mathrm{CO}_{2}$-eq. emissions per kilogram of ECM of the control line cows would benefit slightly more than select line animals by further improvements in ECM yield and feed utilization efficiency. In this study, the nongrazing LFS cows had the lowest $\mathrm{CO}_{2}$-eq. emissions per kilogram of ECM and land use per kilogram of ECM but the highest $\mathrm{CO}_{2}$-eq. emissions per hectare of the production systems studied. If a high forage production system is more economical or health and welfare concerns associated with a nongrazing system dictate that a period at pasture is preferential, then future policy should aim to select dairy genotypes with improved feed utilization efficiency for milk production on a high rather than low forage diet. Improved feed utilization efficiency in dairy cows could also significantly reduce the reliance of the farming system on bought-in synthetic fertilizer and concentrate feed. Future work could incorporate health, welfare, and feed source as impact categories in a whole-system model.

\section{ACKNOWLEDGMENTS}

We are grateful to the farm staff at the SAC Dairy Research Centre for recording the data used in this study and to Ross McGinn (database manager) for maintaining the database. This work is sponsored by The Scottish Government Rural and Environmental Research and Analysis Directorate (RERAD) and SAC. Matt Bell is grateful to RERAD for a postgraduate scholarship.

\section{REFERENCES}

Agrawal, R. C., and E. O. Heady. 1972. Operations Research Methods for Agricultural Decision Analysis. Iowa State University Press, Ames.

Allore, H. G., and H. N. Erb. 1999. Approaches to modeling intramammary infections in dairy cattle. Prev. Vet. Med. 39:279-293.

Basset-Mens, C., S. Ledgard, and M. Boyes. 2009. Eco-efficiency of intensification scenarios for milk production in New Zealand. Ecol. Econ. 68:1615-1625.

Bauman, D. E., S. N. McCutcheon, W. D. Steinhour, P. J. Eppard, and S. J. Sechen. 1985. Sources of variation and prospects for improvement of productive efficiency in the dairy cow: A review. J. Anim. Sci. 60:583-592.

Bell, M. J. 2011a. Modelling the effects of genetic line and feeding system on methane emissions from dairy systems. PhD Dissertation. The University of Edinburgh, UK.

Bell, M. J., E. Wall, G. Russell, D. J. Roberts, and G. Simm. 2010a. Risk factors for culling in Holstein Friesian dairy cows. Vet. Rec. 167:238-240.

Bell, M. J., E. Wall, G. Russell, and G. Simm. 2010b. Effect of breeding for milk yield, diet, and management on enteric methane emissions from dairy cows. Anim. Prod. Sci. 50:817-826.

Bell, M. J., E. Wall, G. Simm, and G. Russell. 2011b. Effects of genetic line and feeding system on methane emissions from dairy systems. Anim. Feed Sci. Technol. In press.

Boeckx, P., and O. van Cleemput. 2001. Estimates of $\mathrm{N}_{2} \mathrm{O}$ and $\mathrm{CH}_{4}$ fluxes from agricultural lands in various regions in Europe. Nutr. Cycl. Agroecosyst. 60:35-47.

Cantrell, K. B., T. Ducey, K. S. Ro, and P. G. Hunt. 2008. Livestock waste-to-bioenergy generation opportunities. Bioresour. Technol. 99:7941-7953.

Capper, J. L., R. A. Cady, and D. E. Bauman. 2009. The environmental impact of dairy production: 1944 compared with 2007. J. Anim. Sci. 87:2160-2167.

Casey, J. W., and N. M. Holden. 2005. Analysis of greenhouse gas emissions from the average Irish milk production system. Agric. Syst. 86:97-114.

Cederberg, C., and B. Mattsson. 2000. Life cycle assessment of milk production-A comparison of conventional and organic farming. J. Clean. Prod. 8:49-60.

Chagunda, M. G. G., D. A. M. Römer, and D. J. Roberts. 2009. Effect of genotype and feeding regime on enteric methane, non-milk nitrogen and performance of dairy cows during the winter feeding period. Livest. Sci. 122:323-332.

Clemens, J., M. Trimborn, P. Weiland, and B. Amon. 2006. Mitigation of greenhouse gas emissions by anaerobic digestion of cattle slurry. Agric. Ecosyst. Environ. 112:171-177. 
Dillon, P. 2006. Achieving high dry-matter intake from pasture with grazing dairy cows. Pages 1-26 in Fresh Herbage for Dairy Cattle, The Key to a Sustainable Food Chain. Vol. 18. A. Elgersma, J. Dijkstra, and S. Tamminga, ed. Springer, Dordrecht, the Netherlands.

Dillon, P., D. P. Berry, R. D. Evans, F. Buckley, and B. Horan. 2006 Consequences of genetic selection for increased milk production in European seasonal pasture based systems of milk production. Livest. Sci. 99:141-158.

FAO (Food and Agriculture Organization of the United Nations). 2010. Greenhouse gas emissions from the dairy sector-A life cycle assessment. Food and Agriculture Organisation, Rome, Italy.

Garnsworthy, P. C. 2004. The environmental impact of fertility in dairy cows: A modeling approach to predict methane and ammonia emissions. Anim. Feed Sci. Technol. 112:211-223.

Gill, M., P. Smith, and J. M. Wilkinson. 2009. Mitigating climate change: The role of domestic livestock. Animal 4:323-333.

Guinée, J. B., M. Gorrée, R. Heijungs, G. Huppes, R. Kleijn, A. de Koning, L. van Oers, A. Wegener Sleeswijk, S. Suh, H. A. Udo de Haes, H. de Bruijn, R. van Duin, M. A. J. Huijbregts, E. Lindeijer, A. A. H. Roorda, B. L. van der Ven, and B. P. Weidema. 2002. Handbook on Life Cycle Assessment: Operational Guide to the ISO Standards. Centrum voor Milieukunde-Universiteit Leiden (CML). Kluwer Academic Publishers, Leiden, the Netherlands.

Haas, G., F. Wetterich, and U. Köpke. 2001. Comparing intensive, extensified and organic grassland farming in Southern Germany by process life cycle assessment. Agric. Ecosyst. Environ. 83:43-53.

Haskell, M. J., L. J. Rennie, V. A. Bowell, M. J. Bell, and A. B. Lawrence. 2006. Housing system, milk production, and zero-grazing effects on lameness and leg injury in dairy cows. J. Dairy Sci. 89:4259-4266.

Hegarty, R. S. 2005. Genotype differences and their impact on digestive tract function of ruminants: A review. Aust. J. Exp. Agric. 44:459-467.

IPCC (Intergovernmental Panel on Climate Change). 2006. 2006 IPCC guidelines for national greenhouse gas inventories. In Agriculture, Forestry and other Land Use. Vol. 4. H. S. Eggleston, L. Buendia, K. Miwa, T. Ngara, and K. Tanabe, ed. Institute for Global Environmental Strategies (IGES), Hayama, Japan.

IPCC (Intergovernmental Panel on Climate Change). 1997. Revised 1996 IPCC Guidelines for National Greenhouse Gas Inventories: Reference Manual. Cambridge University Press, Cambridge, UK.

Lawes Agricultural Trust. 2009. Genstat 11, Version 11.1 Reference Manual. Clarendon Press, London, UK.

Lovett, D. K., L. Shalloo, P. Dillon, and F. P. O'Mara. 2006. A systems approach to quantify greenhouse gas fluxes from pastoral dairy production as affected by management regime. Agric. Syst. 88:156-179.

Martin, C., D. P. Morgavi, and M. Doreau. 2010. Methane mitigation in ruminants: From microbe to the farm scale. Animal 4:351-365.

Mills, J. A. N., L. A. Crompton, A. Bannink, S. Tamminga, J. Moorby, and C. K. Reynolds. 2009. Predicting methane emissions and nitrogen excretion from cattle. J. Agric. Sci. 147:741.

Moran, D., A. Barnes, and A. McVittie. 2007. The rationale for Defra investment in $\mathrm{R} \& \mathrm{D}$ underpinning the genetic improvement of crops and animals (IF0101). Final report to Defra. Defra, London, UK.

National Research Council. 2001. Nutrient Requirements of Dairy Cattle. 7th ed. Natl. Acad. Sci., Washington, DC.

Nielsen, P. H., A. M. Neilsen, B. P. Weidema, R. Dalgaard, and N. Halberg. 2003. LCA food database. Accessed May 10, 2010. www. lcafood.dk/database.
O'Brien, D., L. Shalloo, C. Grainger, F. Buckley, B. Horan, and M. Wallace. 2010. The influence of strain of Holstein-Friesian cow and feeding system on greenhouse gas emissions from pastoral dairy farms. J. Dairy Sci. 93:3390-3402.

Pollott, G. E., and M. P. Coffey. 2008. The effect of genetic merit and production system on dairy cow fertility, measured using progesterone profiles and on-farm recording. J. Dairy Sci. 91:3649-3660.

Pryce, J. E., B. L. Nielson, R. F. Veerkamp, and G. Simm. 1999 Genotype and feeding system effects and interactions for health and fertility traits in dairy cattle. Livest. Prod. Sci. 57:193-201.

Santarossa, J. M., A. W. Stott, J. A. Woolliams, S. Brotherstone, E. Wall, and M. P. Coffey. 2004. An economic evaluation of long-term sustainability in the dairy sector. Anim. Sci. 79:315-325.

Sjaunja, L. O., L. Baevre, L. Junkkarinen, J. Pedersen, and J. Setala. 1990. A Nordic proposal for an energy corrected milk (ECM) formula. 27th Session Int. Commission for Breeding and Productivity of Milk Animals, Paris, France.

Steinfeld, H., P. Gerber, T. Wassenaar, V. Castel, M. Rosales, and C. de Haan. 2006. Livestock's long shadow: Environmental issues and options. Food and Agriculture Organisation, Rome, Italy.

Stott, A. W., R. F. Veerkamp, and T. R. Wassell. 1999. The economics of fertility in the dairy herd. Anim. Sci. 68:49-57.

Thomas, P. C., S. Robertson, D. G. Chamberlain, R. M. Livingstone, P. H. Garthwaite, P. J. S. Dewey, R. Smart, and C. Whyte. 1988 Predicting the metabolizable energy (ME) content of compound feeds for ruminants. Pages 127-146 in Recent Advances in Animal Nutrition. W. Haresign, and D. J. A. Cole, ed. Butterworths, London, UK.

Thomassen, M. A., K. J. van Calker, M. C. J. Smits, G. L. Iepema and I. J. M. de Boer. 2008. Life cycle assessment of conventional and organic milk production in the Netherlands. Agric. Syst. 96:95-107.

UKGGI (UK Greenhouse Gas Inventory). 2010. 1990 to 2008 annual report for submission under the framework convention on climate change. Defra, London, UK.

VandeHaar, M. J., and N. St Pierre. 2006. Major advances in nutrition: Relevance to the sustainability of the dairy industry. J. Dairy Sci. 89:1280-1291.

Veerkamp, R. F., and S. Brotherstone. 1997. Genetic correlations between linear type traits, feed intake, live weight and body condition score in Holstein Friesian dairy cattle. Anim. Sci. 64:385-392.

Veerkamp, R. F., S. Brotherstone, B. Engel, and T. H. E. Meuwissen 2001. Analysis of censored survival data using random regression models. Anim. Sci. 72:1-10.

Veerkamp, R. F., G. C. Emmans, A. R. Cromie, and G. Simm. 1995 Variance components for residual feed intake in dairy cows. Livest. Prod. Sci. 41:111-120.

Wainman, F. W., P. J. S. Dewy, and A. C. Brewer. 1984. Feedingstuffs Evaluation Unit, Fourth Report 1984. Rowett Research Institute, Aberdeen, UK.

Wall, E., G. Simm, and D. Moran. 2010. Developing breeding schemes to assist mitigation of greenhouse gas emissions. Animal 4:366376.

Yan, T., C. S. Mayne, F. G. Gordon, M. G. Porter, R. E. Agnew, D. C. Patterson, C. P. Ferris, and D. J. Kilpatrick. 2010. Mitigation of enteric methane emissions through improving efficiency of energy utilization and productivity in lactating dairy cows. J. Dairy Sci. 93:2630-2638. 